\title{
Production method and cost of commercial-scale offshore cultivation of kelp in the Faroe Islands using multiple partial harvesting
}

\author{
Grandorf Bak, Urd; Mols-Mortensen, Agnes; Gregersen, Olavur
}

\section{Published in:}

Algal Research

Link to article, DOI:

10.1016/j.algal.2018.05.001

Publication date:

2018

Document Version

Peer reviewed version

Link back to DTU Orbit

\section{Citation (APA):}

Grandorf Bak, U., Mols-Mortensen, A., \& Gregersen, O. (2018). Production method and cost of commercialscale offshore cultivation of kelp in the Faroe Islands using multiple partial harvesting. Algal Research, 33, 3647. https://doi.org/10.1016/j.algal.2018.05.001

\section{General rights}

Copyright and moral rights for the publications made accessible in the public portal are retained by the authors and/or other copyright owners and it is a condition of accessing publications that users recognise and abide by the legal requirements associated with these rights.

- Users may download and print one copy of any publication from the public portal for the purpose of private study or research.

- You may not further distribute the material or use it for any profit-making activity or commercial gain

- You may freely distribute the URL identifying the publication in the public portal 


\section{Title}

Production method and cost of commercial-scale offshore cultivation of kelp in the Faroe Islands using multiple partial harvesting

\section{Authors}

Urd Grandorf Bak ${ }^{1,2}$

Agnes Mols-Mortensen ${ }^{3,4}$

Olavur Gregersen ${ }^{1, *}$

*Corresponding author: olavur@oceanrainforest.com, Ocean Rainforest Sp/f, Mjólkargøta 20, FO-180 Kaldbak, Faroe Islands.

\section{Affiliation and address of the authors}

${ }^{1}$ Ocean Rainforest Sp/f, Mjólkargøta 20, FO-180 Kaldbak, Faroe Islands.

${ }^{2}$ National Food Institute, Technical University of Denmark, Kemitorvet, Building 202, Room 3132, 2800 Kgs. Lyngby, Denmark.

${ }^{3}$ Fiskaaling - Aquaculture Research Station of the Faroes, FO-430 Hvalvík, Faroe Islands.

${ }^{4}$ TARI - Faroe Seaweed Sp/f., Vípuvegur 14, FO-100 Tórshavn, Faroe Islands.

\section{E-mail and phone}

urd@oceanrainforest.com, +45 30264595

agnes@tari.fo,+298 210708

olavur@oceanrainforest.com, +298 233080 


\section{Abstract}

The current work aimed to develop a cultivation method for macroalgae that can be applicable and economically profitable in the Atlantic Ocean. An offshore long-line macroalgal cultivation rig was designed by Ocean Rainforest Sp/f, tested in the Faroe Islands from 2010, and found suitable for cultivation in exposed and deep-water locations (water depth $>50 \mathrm{~m}$ ). The economic risk related to lost cultivation structures was hereafter considered to be low. Saccharina latissima and Alaria esculenta were cultivated in commercial scale (5 km of growth lines). A high cost of seeding material and cost of deployment was reduced by testing multiple partial harvesting. Four non-destructive harvests were carried out in a two-year growth period without re-seeding of lines. In total, 3.2 tonnes dry weight (dw) biomass was harvested and sold to customers within the food and cosmetic industries. The gross-productivity was $879.3-1,437.5 \mathrm{~kg} \mathrm{dw}$ $\mathrm{ha}^{-1} \mathrm{yr}^{-1}$ (including handling space), and the net productivity was $35,172-57,500 \mathrm{~kg} \mathrm{dw} \mathrm{ha}^{-1} \mathrm{yr}^{1}$ (only including space used for growth). The variance of productivity reflects the difference between real harvest data and extrapolated yield from growth measurements. The 10 -meter vertical growth lines had an average yield of $0.29 \mathrm{~kg} \mathrm{dw} \mathrm{m}^{-1}$ line-per harvest and when using a 10 -meter vertical growth line and-four partial harvests were made over a 2-year period. An economic analysis showing the cost structure of important aspects of offshore macroalgae cultivation was conducted. The total cost per $\mathrm{kg} \mathrm{dw}$ of cultivated S. latissima decreased when the number of possible harvests without re-seeding was increased (from $€ 36.73$ to $€ 9.27$ ). This work has demonstrated that large-scale kelp cultivation is possible using multiple partial harvesting in the Faroe Islands, and highlighted the need for further innovation to lower the cost per unit macroalgal produced.

\section{Keywords}

Offshore cultivation; Economic; Saccharina latissima; Alaria esculenta; The Faroe Islands; Multiple partial harvesting 


\section{Abbreviations}

MACR, MacroAlgae Cultivation Rig; MBSL, meter below sea level; dw, dry weight; ww, wet weight; SD, standard deviation; ha, hectare

\section{Introduction}

The need for food is increasing globally and, therefore, the efficient use of natural resources is increasingly vital. Most land areas are already utilized for the conventional agriculture of terrestrial plants. However, the oceans, that cover more than $70 \%$ of the planet, potentially offer solutions for future sustainable large-scale biomass production. The use of macroalgae (seaweeds) has a long history, as does the cultivation at sea of a relatively small group of macroalgal species [1]. In North America and in Europe, macroalgae are a relatively underexploited resource, though they are the subject of an increasing interest for their potential as human food, animal feed, cosmetics, bioactive components, and biofuel [2-8]. The interest in macroalgal cultivation is driven by a market demand $[1-2,8]$ and because of environmental concerns related to wild harvest of macroalgae [9-11].

Cultivation of macroalgae has important environmental benefits compared to harvesting wild populations. Instead of damaging natural ecosystems, new artificial marine forests are established with similar environmental functions as a nursery habitat for juvenile fish and as a food source for animals. The cultivated macroalgal biomass bioremediates nutrients and carbon $\left(\mathrm{CO}_{2}\right)$ from the surrounding environment as biomass [3,9-10]. There is therefore an ecological benefit to be gained from the cultivation of macroalgae.

The European macroalgal industry currently relies on wild harvesting, unlike Asian producers that mainly rely on cultivation. In 2015, Asia produced 27 million tonnes wet weight (ww) macroalgal biomass, corresponding to approximately 2.7 million tonnes dry weight (dw), whereas the yield in Europe was only a few hundred tonnes dw [12]. The cultivation methods developed in Asia through centuries are not easily applicable to the western countries. The reason is that the cultivation methods that are used are labour intensive, and the methods are not proven to be profitable in the Western world [2,13]. Zuniga-Jara et al. 
[14] made a feasibility study of offshore commercial kelp cultivation in Chile, and concluded that it was not profitable, as the sale of the biomass was unable to cover the investment costs or the operation costs.

To reduce production cost, Burg et al. [2] described the importance of developing a cultivation system that enables multiple partial harvests. Furthermore, biofouling seems to be a major issue for cultivation in Europe $[8,15-18]$, and the phenomenon appears to be coupled to relatively sheltered locations preventing the use of multiple partial harvesting [5,19]. Offshore cultivation, therefore, seems to be vital for a profitable macroalgal industry $[5,20-21]$.

Offshore cultivation is defined as "the execution of activities in sites that are subject to ocean waves", which is linked to distance from shore or lack of shelter from topographical features such as islands or headlands that can mitigate the force of ocean and wind-generated waves and sites with significant wave heights of two meters or above [22].

Producing macroalgae offshore is thus promising in terms of market potential and sustainability, but an extremely challenging endeavour [2-4,7,20,23-27].

Relatively few macroalgal species have been utilized for production [1], nevertheless, kelps have been exposed to some of the first pioneer cultivation trials in North America and in Europe. The two kelp species Saccharina latissima (Linnaeus) Lane, Mayes, Druehl and Saunders, commonly known as "sugar kombu" or "sugar kelp", and Alaria esculenta (Linnaeus) Greville, with the common name "winged kelp", have attracted commercial interest for human consumption as sea-vegetables $[8,17,26]$. S. latissima grows on the lower shore in semi-exposed areas, whereas A. esculenta is very tolerant to more severe wave exposure. Both algae are distributed along the northern Atlantic coasts and in Arctic areas. S. latissima is also found along the northern Pacific coasts and is distributed in oceans with higher temperatures and lower salinities than A. esculenta. The cultivation techniques are well developed for both species, and especially S. latissima is described as having good potential for commercial-scale cultivation in Europe and in the North Atlantic $[2,28]$.

During the past decades, several macroalgal cultivation trials have been conducted in the Atlantic Ocean in particularly using S. latissima [26,28-35]. However, none of these cultivation trials have resulted in large-scale profitable cultivation [2]. 
This paper describes the work of several years innovative large-scale kelp cultivation in the Faroe Islands, documenting the use of a new concept for offshore cultivation installation: the Macroalgal Cultivation Rig (MACR). Also, the effect on economics of multiple partial harvesting of S. latissima and A. esculenta was described for the first time. The cultivation data reflects the large variation in growth and provides a reliable base-line study of pioneer kelp cultivation for the future use in European and North American oceans.

\section{Material and Methods}

\subsection{Cultivation site and environmental conditions}

The macroalgal cultivation site was located at the mouth of Funningsfjørður in the Faroe Islands $\left(62.3030^{\circ} \mathrm{N}, 6.9267^{\circ} \mathrm{W}\right.$; Fig. 1). The Faroe Islands are an archipelago situated in the Northeast Atlantic Ocean. The site had a water depth of 50-70 m, was exposed to currents of $15-25 \mathrm{~cm} \mathrm{~s}^{-1}$ and was characterized as an exposed area with occasional significant wave heights of 3-6 m [36-39]. The North Atlantic Current, which originates from the warm Gulf Stream, runs past the Faroe Islands and brings warm currents to the area, providing a relatively stable seawater temperature ranging from 6 to $11^{\circ} \mathrm{C}$ during the year [40]. The salinity was very stable at 35.0-35.2 [40]. Contrary to salinity, the irradiance and day length varied substantially through the year. Irradiance measured at land surface varied from less than $50 \mu \mathrm{E} \mathrm{m} \mathrm{m}^{-2} \mathrm{~s}^{-1}$ in November to February and up to $300 \mu \mathrm{E} \mathrm{m}^{-2} \mathrm{~s}^{-1}$ in average during May [41]. There was a large drop in irradiance when penetrating sea surface due to reflection. In the seawater column light can penetrate down to $30-50$ meter below sea level (MBSL), though at these depths the irradiance was very low $\left(<10 \mu \mathrm{E} \mathrm{m}^{-2}\right.$ $\mathrm{s}^{-1}$ ). There was a linear relationship between the phytoplankton concentration and the attenuation coefficient, which varied between 0.05 and $0.3 \mathrm{~m}^{-1}[41]$. 


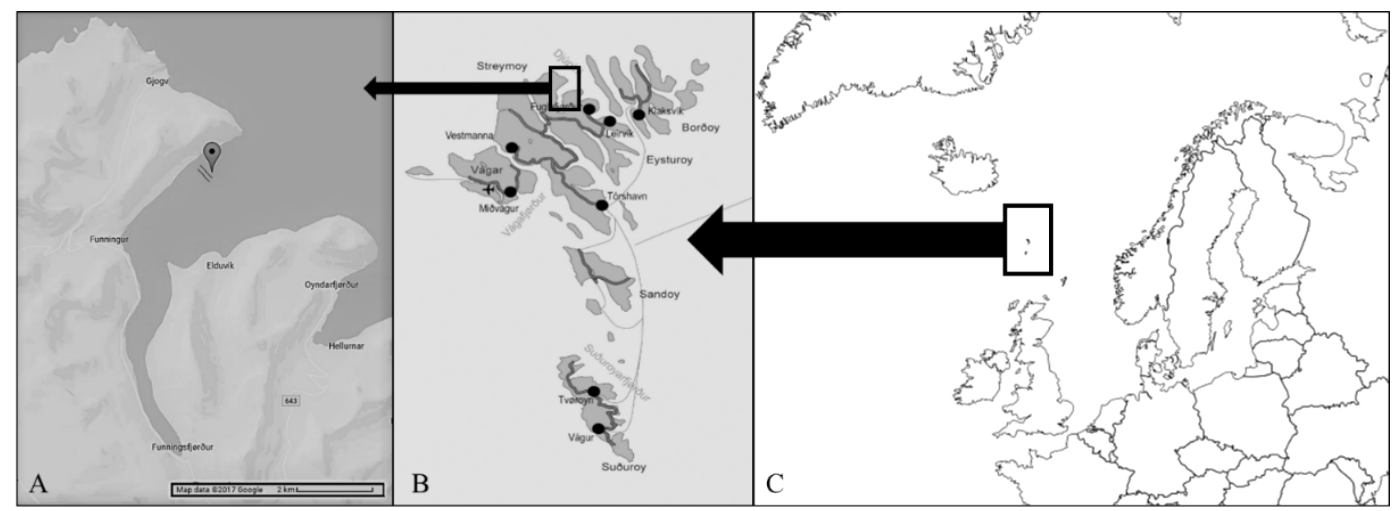

Fig. 1. Maps of the cultivation site in Funningsfjørður (A, (C) Google), the Faroe Islands (B, (C Kort- og Martrikelstyrelsen), in the North Atlantic Ocean (C, (C) Wikimedia Commons, the free media repository).

\subsection{Cultivation system}

The Macroalgae Cultivation Rig (MACR) developed by the company Ocean Rainforest Sp/f was designed to withstand the conditions of the North Atlantic Ocean (Fig. 2). The MACR was constructed using lightweight and robust equipment. None of the parts were specially designed, as all equipment was bought from a local manufacturer selling fishing gear, aquaculture equipment, and equipment to the offshore industry.

The design consisted of a 500-m long polysteel fix line (30 mm in diameter) suspended horizontally at 10 MBSL (C, Fig. 2). Two main surface floats (D, Fig. 2) were connected to the fix line and $40 \%$ submerged in a static state. The mooring system consisted of four 120-m anchor lines, which were attached to the fix line and anchored to the seafloor with 1-1.5 tonne steel anchors (E, Fig. 2). One MACR occupied a sea surface area of 1 ha (one MACR has a nominal width of $10 \mathrm{~m}$ on each side of the fix line). The rig had approximately 250 growth lines (B, Fig. 2) of 10-m length attached to the fix line with a float fixed at the opposite end, stretching the lines in a vertical position.

The first test MACR was deployed in March 2010 and the growth lines attached were not seeded. After a successful structural testing period of three years, the growth lines were replaced with seeded lines with respectively S. latissima and Laminaria hyperborea (Gunnerus) Foslie. This deployment was meant as a biological test of growth. Unfortunately, these results were not consistent enough for scientific 
purposes, but important lessons were learnt in terms of practical handling of seeding, deployment, maintenance and harvesting. In November 2014, two more MACR's were deployed and these lines provide the data information on the growth and costs in this paper.

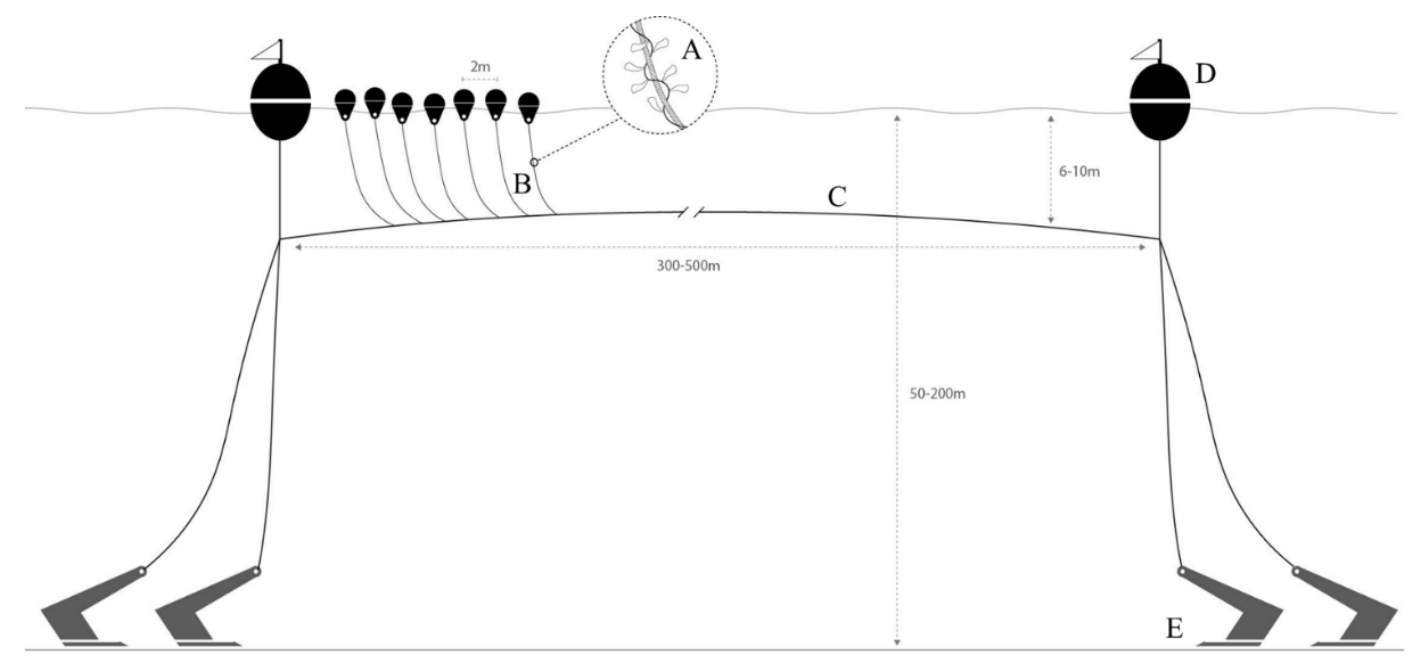

Fig. 2. Schematic drawing of a Macroalgal Cultivation Rig (MACR) constructed by Ocean Rainforest Sp/f. The construction can be deployed for macroalgal cultivation at wave-exposed sites with a water depth of 50-200 m. Seed lines (A) are twined around growth lines $(\boldsymbol{B})$ that are attached at 2-m intervals to the fix line $(\boldsymbol{C})$ by a loop and held in a vertical position by a buoy. Two main surface floats $(D)$ and four steel anchors $(E)$ ensure the right position of the rig.

\subsection{Seeding method}

Seeding material was produced by the company Hortimare BV, located in Norway and the Netherlands, using a standard procedure for kelp sporulation [42]. Fertile S. latissima and A. esculenta were collected from wild populations in Funningsfjørður in January 2014. From the sterilized fertile sori, spore release was done by leaving the sori dehydrating and in darkness until next day. The spores were released to sterile and filtrated seawater and placed with aeration in red light at $10 \pm 2{ }^{\circ} \mathrm{C}$. The gametophytes were nursed till sufficient biomass was reached (cultivated in vitro for $>9$ months). Hereafter, an induction period using white light was initiated. The gametophytes developed into juvenile sporophytes within two weeks (size $<1 \mathrm{~mm}$ ). Density of the seeding material was approximately $0.04 \mathrm{~mL} \mathrm{~m}^{-1}$ seeded line or a minimum of 200 sporophytes $\mathrm{m}^{-1}$. The juvenile sporophytes were seeded on 2-mm lines using a binder-mixture 
produced by Devan Chemicals N.V. with the product code DG518. The seed lines were twined around coils and the juvenile sporophytes were cultivated in hatchery tanks for a three-week period before deployment. The cultivation conditions as light, nutrients, waterflow, etc. is IPR of Hortimare.

\subsection{Deployment}

The juvenile sporophytes were deployed at sea in November 2014. The day before deployment, the seed lines (A, Fig. 2) were twined around a growth line (B, Fig. 2) of 14-mm polypropylene three strained twisted rope. The growth lines with juvenile macroalgae were stored in seawater until transportation. These growth lines summed up to a total of 470 , each of $10 \mathrm{~m}$ length and attached along the fix line (C, Fig. 2) with a 2-m interval and each line had a buoy attached in the opposite end to provide uplift. Two MACR's were completed with 4200 meter of S. latissima growth lines and 500 meter of A. esculenta growth lines. The two rigs were named MACR1 and MACR2. All the A. esculenta lines were cultivated on MACR2 and the 50 lines were placed next to each other on the fix line.

\subsection{Multiple partial harvesting}

The biomass of $S$. latissima was harvested in early summer (27/5-29/6) and late summer (24/7-24/8) during 2015 and 2016 by the company Ocean Rainforest Sp/f. The harvest method was manual cutting with a knife. Only the blades were cut off; leaving hold-fast, stem and 5-15 cm of the blade. This cutting length was used to ensure preservation of the meristematic zone to allow re-growth (Fig. 3). The biomass of $A$. esculenta was also harvested by the non-destructive multiple partial harvesting, once in the summer 2015 and twice in the summer 2016. The optimal cutting length of $A$. esculenta has not been described previously, because the multiple partial harvesting method has not been tested for this species before. Hence, the $A$. esculenta was harvested in two different ways to find the optimal cutting length. At this farm scale level of cultivation, it was not possible to perform a randomized experimental design. Consequently, the two types of treatment were placed after each other on the fix line with 25 lines of each treatment uninterrupted. One half of the lines $(n=25)$ was cut proximally to the sporophylls, only leaving holdfast and part of stem, and 
the other half the lines $(\mathrm{n}=25)$ was cut distally to the sporophylls leaving $5-15 \mathrm{~cm}$ of blade, entire holdfast, stem and sporophylls.

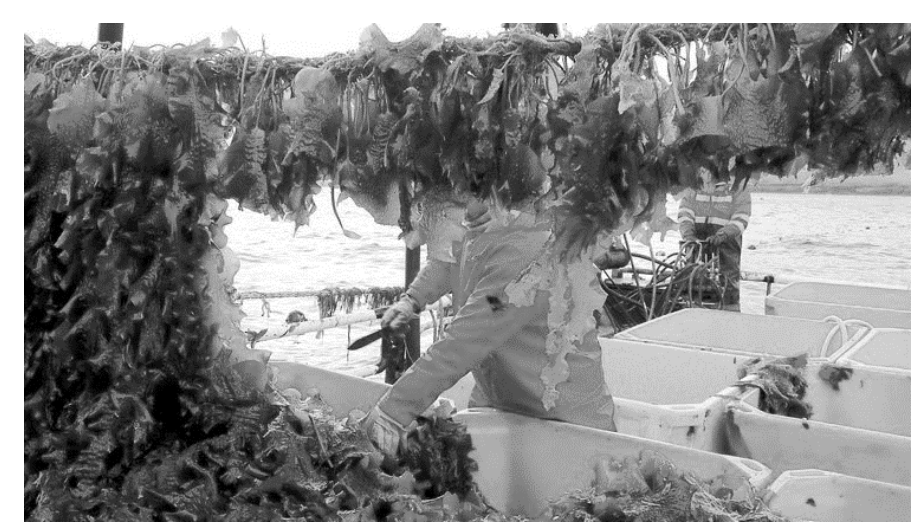

Fig. 3. Manual harvesting of Saccharina latissima in Funningsfjørður, Faroe Islands, August 2016 (Photo by Anja Mazuhn).

\subsection{Yield, processing and storage of harvested biomass}

The harvested macroalgal biomass was transported in large plastic containers $(123 \times 103 \times 75 \mathrm{~cm} ; 660$ L) from the boat to the processing facilities. The biomass was cleaned carefully with seawater, before it was either dried at $35^{\circ} \mathrm{C}$ for $1-2$ days and packed in boxes of $80 \mathrm{~kg} \mathrm{dw}$, or immediately frozen in a chest freezer at $-40{ }^{\circ} \mathrm{C}$ and stored at $-20^{\circ} \mathrm{C}$ in boxes of $10 \mathrm{~kg} \mathrm{ww}$.

The harvested and packed macroalgal biomass was used to describe yield. Discarded biomass was, therefore, not included in final yield calculation. Though the discarded biomass was estimated to be less than $25 \%$ of total harvested biomass, this needs to be considered as an error source of yield calculations. The macroalgal biomass was occasional discarded on-board at sea, if it was covered by severe fouling, or during packaging, if colour/appearance or taste was not right. In an optimal production situation, there will be zero waste as discarded biomass will be used as feed, fertilizer, or extraction for high value molecules.

To compare the yield from this work with those described in the literature, the Aquaculture Outputproductivity was calculated_as: yield per unit of space per year. The productivity of one MACR

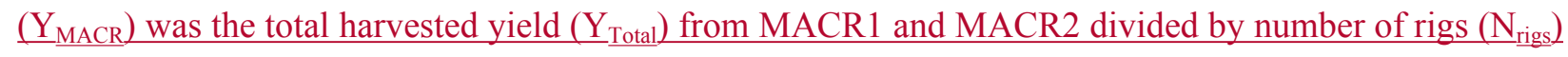
and divided by the years of harvests from the same lines $\left(\mathrm{N}_{\text {years }}\right)$ :

$$
\underline{Y}_{\underline{M A C R}}=Y_{\text {Total }} / N_{\text {rigs }} / N_{\text {vears }}=\underline{\mathrm{kgdw} / \mathrm{rig} / \mathrm{yr}}
$$


The productivity of one hectare was calculated using productivity of one MACR $\left(\mathrm{Y}_{\mathrm{MACR}}\right)$ divided by

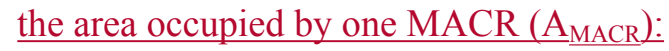

$$
\underline{A O} \underline{M A C R}=Y_{M A C R} / A_{M A C R}=\mathrm{kgdw} / \mathrm{ha} / \mathrm{yr}
$$

Spacing (used area) is a smaller or larger issue depending on the cultivation location and type of eultivation system and, in the literature, the space used for handling a system is therefore sometimes included, gross productivity, and sometimes not, net productivity.

To calculate the sea surface area utilized in this work, it was necessary to make the following two assumptions. The area occupied by one $\operatorname{MACR}\left(\mathrm{A}_{\mathrm{MACR}}\right)$ were determined by the length of the fix line $\left.\underline{\mathrm{L}}_{\mathrm{MACR}}\right)$ times the width used for handling the rig $\left(\mathrm{W}_{\mathrm{MACR}}\right)$ added on both sides:

$$
\begin{gathered}
\text { Assumption 1: } A_{M A C R}=L_{M A C R} \cdot 2\left(W_{M A C R}\right)_{2} \\
\text { in this case: } 500 \mathrm{~m} \cdot 2(10 \mathrm{~m})=10,000 \mathrm{~m}^{2}=1 \mathrm{ha}
\end{gathered}
$$

Thus, one MACR occupied a sea surface area of one hectare (ha) including space for handling the rig, as the fix lines used was 500-m, and the width used for handling was set to $10-\mathrm{m}$ of space added to both sides of the fix line.

The area occupied by one vertical growth line $\left(\mathrm{A}_{\mathrm{GL}}\right)$ were determined by the length between growth lines $\left(\mathrm{Lb}_{\mathrm{GL}}\right)$ times the width which a growth line occupies $\left(\mathrm{W}_{\mathrm{GL}}\right)$ :

$$
\begin{aligned}
& \text { Assumption } 21: A_{G L}=L b_{G L} \cdot W_{G L}, \\
& \text { in this case: } 2 \mathrm{~m} \cdot 0.5 \mathrm{~m}=1 \mathrm{~m}^{2}
\end{aligned}
$$

Thus, one growth line occupied a netsea surface area of one square meter $\left(\mathrm{m}^{2}\right)$ not including space for handling the line, as the length between growth lines was two meters, and the width was set to be a half meter based on the occupied space of a buoy.

The area occupied by one MACR $\left(A_{\text {MACR }}\right)$ were determined by the length of fix line ( $\left.\mathrm{I}_{\text {MACR }}\right)$ times the width used for handling the rig ( $\left.\mathrm{Wh}_{\mathrm{MACR}}\right)$ added on both sides:

$$
\begin{gathered}
\text { Assumption 2: } A_{A A C R}=L_{A A C R} \cdot 2\left(W h_{A A C R}\right), \\
\text { in this case: } 500 \mathrm{~m} \cdot 2(10 \mathrm{~m})=10,000 \mathrm{~m}^{2}=1 \mathrm{hat}
\end{gathered}
$$

Thus, one MACR occupied a gross sea surface area of one hectare (ha) including space for handling the rig, as the fix lines used was $500-\mathrm{m}$, and the width used for handling was set to $10 \mathrm{~m}$ of space added to 
both sides of the fix line. However, the related net sea surface area of one MACR was $250 \mathrm{~m}^{2}$ or $0,025 \mathrm{ha}$ (ref. assumption 1). The difference in the metric notion between gross and net usage of a ha is significant, and in this present case the difference between yield $\mathrm{ha}^{-1} \mathrm{yr}^{-1}$ is a factor of 40 .

The productivity of one MACR was calculated in two ways using: 1) the real harvest data and 2) the extrapolated yield.

1) Real harvest data of one MACR $\left(\mathrm{Y}_{\mathrm{MACR}}\right)$ : The total harvested yield $\left(\mathrm{Y}_{\text {Total }}\right)$ from MACR 1 and 2 divided by number of rigs $\left(\mathrm{N}_{\text {rigs }}\right)$ and divided by the years of harvests from the same lines $\left(\mathrm{N}_{\text {years }}\right)$ :

$$
Y_{\text {MACR }}=Y_{\text {Total }} / \mathrm{N}_{\text {rigs }}+\mathrm{N}_{\text {years }}=\mathrm{kg} \mathrm{dw} / \mathrm{rig} / \mathrm{yr}
$$

2) Extrapolated yield of one growth line $\left(\mathrm{Y}_{G t}\right)$ : The average yield per harvest per meter line $\left(\mathrm{Y}_{\mathrm{m}}\right)$, times the total number of harvests per year $\left(\mathrm{N}_{\text {harvests }}\right)$, times the total meter of growth line on one MACR $\left(\mathrm{M}_{\mathrm{GL}}\right) \div$

$$
Y_{G L}=Y_{m} * N_{\text {harrests per year }} * M_{G L}=\mathrm{kg} d w / \text { line } / \mathrm{yr}
$$

Net Aquaculture Output ( $\left(\mathrm{A}_{\mathrm{GL}}\right)$ was found from the extrapolated yield $\left(\mathrm{Y}_{\mathrm{GL}}\right)$ divided by the area eccupied by one vertical growth line $\left(\mathrm{A}_{\mathrm{GL}}\right)$ :

$$
A \theta_{G t}=Y_{G t}+A_{G t}=k g d w / m^{2}+y r
$$

Gross Aquaculture Output ( $A \Theta_{\text {MACR }}$ ) was calculated using the real harvest data $\left(Y_{\text {MACR }}\right)$ divided by the area occupied by one $\operatorname{MACR}\left(\mathrm{A}_{\mathrm{MACR}}\right)$ :

$$
A O_{\text {MACR }}=Y_{\text {MACR }} / A_{\text {MACR }}=\mathrm{kg} d w / h a / y r
$$

\subsection{Conversion factor between fresh and dry macroalgae biomass}

In all calculations of wet weight (ww) biomass to dried biomass (dw) or opposite a conversion-factor of 10:1 was used [43-44]. All cultivation results described as yield in dw, and reference to results from the literature was also described as dw, but also as ww, if they were initially recorded or presented in ww.

\subsection{Growth measurement}


Growth of S. latissima deployed in November 2014 was monitored monthly over a period of two years. For each meter the six longest algal individuals were measured as technical replicates. The average of each meter was used to describe the average maximal length and compared with biological replicates $(n=3)$. The length was measured from growth line to tip of alga. The length was measured at five different depth intervals (1-2, 3-4, 5-6, 7-8 and 9-10 MBSL) and the average length of the vertical growth line was used $(n=3)$. Note that the surface meter was not used, though this was often the best producing meter, but here other species often overtook the line e.g. A. esculenta and Laminaria digitata (Hudson) J.V. Lamouroux. The average maximal length was used for statistical treatment to compare replicate lines, cultivation in depth, and in different seasons.

Also, the number of visible individuals on each meter was counted and used in the data treatment. Number of individuals and average maximal length provided a comparable dataset for growth under various conditions, but was not used to calculate the yield.

Finally, a field inspection was made to determine length and yield per meter line and at different depths prior to harvesting. The average maximal length of the macroalgae on the inspection days was the same data as for the seasonal variation in growth. For the yield calculations, a meter of line was harvested and weighted on board using a hand-held scale $(n=2-4)$. The field inspections were made May 2015, Aug 2015, and May 2016 at ten different depths $(0-1,1-2, \ldots$ 9-10 MBSL). These numbers of yield serve as a yield-calculation without errors of discarded biomass.

The study did not include a control treatment: non-harvested lines growing throughout 2014-2016. Data of growth and yield could, therefore, not be compared to non-harvested reference lines.

\subsection{Formulation of cost functions}

To show the underlying cost structure of macroalgal cultivation using a MACR we formulated the cost functions. The yearly cost of investment in terms of capital expenditure (CAPEX) on a MACR was subdivided into expenditure on the cultivation rig $\left(\mathrm{TC}_{\mathrm{RIG}}\right)$ and on the growth lines $\left(\mathrm{TC}_{\mathrm{GL}}\right)$, divided by the number of years over which the rig $\left(\mathrm{d}_{\mathrm{RIG}}\right)$ and the growth lines $\left(\mathrm{d}_{\mathrm{GL}}\right)$ were depreciated: 


$$
C A P E X_{T O T A L}=T C_{R I G} / d_{R I G}+T C_{G L} / d_{G L}
$$

where $\mathrm{TC}_{\mathrm{RIG}}$ was the total cost of the rig and $\mathrm{TC}_{\mathrm{GL}}$ was the total cost of the growth lines. The total cost of a rig was subdivided into the sum of material costs $\left(\mathrm{MC}_{\mathrm{RIG}}\right)$ and deployment costs $\left(\mathrm{DC}_{\mathrm{RIG}}\right)$ :

$$
T C_{R I G}=M C_{R I G}+D C_{R I G}
$$

The material costs $\left(\mathrm{MC}_{\mathrm{RIG}}\right)$ included costs of anchors, chains, the fix line, fittings, surface floats and signal buoys. The deployment costs (DC) were the hourly cost of vessel operation offshore, the hourly cost of labour and the total number of operation hours needed for deployment. To determine the total cost of the growth lines $\left(\mathrm{TC}_{\mathrm{GL}}\right)$ on a MACR-installation, the cost of a single growth line $\left(\mathrm{C}_{\mathrm{GL}}\right)$ was multiplied by the number of growth lines $\left(\mathrm{N}_{\mathrm{GL}}\right)$ :

$$
T C_{G L}=N_{G L} \cdot C_{G L}
$$

The deployment and installation of growth lines included material for preparation, strips, and tape, twining seed lines around growth lines and transport of growth lines for installation offshore on the fix line.

The operational expenditures (OPEX) involved cultivation offshore, monitoring, maintenance, and harvesting, and were formulated as follows:

$$
O P E X=O C \cdot N_{\text {harvests per year }}
$$

where $\mathrm{N}_{\text {harvests per year }}$ indicates the number of harvests in a year and $\mathrm{OC}$ is the operational cost for one growth period. The operational cost (OC) was the hourly cost of vessel operation offshore, plus the hourly cost of labour, multiplied by the number of hours spent on each inspection times the number of inspections in each growth period, plus the time spent on harvesting each growth line times by the number of growth lines.

$$
O C=\left(p_{\text {vessel }}+p_{\text {labour }}\right) \cdot\left(q_{\text {inspection hours }} \cdot N_{\text {inspections }}+q_{\text {harvesting hours }} \cdot N_{G L}\right)
$$

To determine the revenue function and the cost per unit macroalgae we identified the yield of harvested biomass during the growth period. The yield $(\mathrm{Y})$ in $\mathrm{kg} \mathrm{dw}$ is calculated as:

$$
Y=G \cdot N_{G L} \cdot q_{\text {rope }} \cdot N_{\text {harvests per year }}
$$

where $\mathrm{G}$ is the average growth of macroalgae per growth period in $\mathrm{kg}$ dw per meter growth line, $\mathrm{N}_{\mathrm{GL}}$ is the number of growth lines, and $\mathrm{q}_{\mathrm{rope}}$ is the length of each growth line. The average cost per unit algal biomass (AVC) was calculated as:

$$
A V C=(C A P E X+O P E X) / Y
$$




\section{Results}

\subsection{Cultivation System}

Since deployment of the first MACR in March 2010 and the following two MACR's deployed in 2014, the installations have remained intact in the ocean and have proven themselves able to withstand the physical strains caused by the energetic wave climate and storms of the North Atlantic Ocean.

\subsection{Harvest and yield}

The two 500-m long MACR's that were deployed at the cultivation site in November 2014 had a total of 470 vertical 10-m long growth lines. The total of growth lines seeded with Saccharina latissima was 420 and for Alaria esculenta 50 lines. The S. latissima lines were partially harvested four times and the A. esculenta lines were partially harvested three times within the harvest season in 2015 and 2016 (Table 1). The total biomass harvested $\left(\mathrm{Y}_{\text {Total }}\right)$ over two years for all three seaweed species was $3,517.6 \mathrm{~kg} \mathrm{dw}$. The annual productivity of one MACR $\left(\mathrm{Y}_{\mathrm{MACR}}\right)$ was thus $879.4 \mathrm{~kg} \mathrm{dw} \mathrm{yr}^{-1}$.

Table 1. Results of multiple partial harvesting from two Macroalgae Cultivation Rig's (MACR) deployed offshore in the Faroe Islands. MACR 1 had 240 and MACR 2 had 230 of 10-m long growth lines attached. Results marked with * were estimated from total harvest of 2015 using number of lines harvested in each period. Results marked with \# were possibly overestimated because self-seeded Alaria esculenta growing on Saccharina latissima-lines were included in the yield calculation.

\begin{tabular}{|c|c|c|c|c|c|}
\hline Deployed: Nov. 2014 & MACR & $1^{\text {st }}$ harvest & $2^{\text {nd }}$ harvest & $3^{\text {rd }}$ harvest & $4^{\text {th }}$ harvest \\
\hline \multirow[t]{2}{*}{ Harvest periods } & 1 & $\begin{array}{c}\text { May/June } \\
2015\end{array}$ & $\begin{array}{c}\text { July/Aug. } \\
2015\end{array}$ & $\begin{array}{c}\text { May/June } \\
2016\end{array}$ & $\begin{array}{c}\text { July/Aug. } \\
2016\end{array}$ \\
\hline & 2 & June 2015 & $\begin{array}{c}\text { Aug./Sept. } \\
2015 \\
\end{array}$ & $\begin{array}{c}\text { May/June } \\
2016 \\
\end{array}$ & Aug. 2016 \\
\hline \multirow[t]{2}{*}{ Days used } & 1 & 8 & 9 & 7 & 4 \\
\hline & 2 & 4 & 6 & 9 & 3 \\
\hline \multirow[t]{2}{*}{ Meters harvested } & 1 & 610 & 1700 & 1600 & 1400 \\
\hline & 2 & 830 & 1250 & 1980 & 1330 \\
\hline \multirow[t]{2}{*}{$\%$ harvested of total deployed } & 1 & $25 \%$ & $71 \%$ & $67 \%$ & $58 \%$ \\
\hline & 2 & $36 \%$ & $54 \%$ & $86 \%$ & $58 \%$ \\
\hline
\end{tabular}




\begin{tabular}{|l|l|r|r|r|r|}
\hline Yield S. latissima in total & $\mathrm{kg} \mathrm{dw}$ & $\mathbf{3 4 7 . 2}$ & $\mathbf{7 8 7 . 8}$ & $\mathbf{1 0 2 6 . 3}$ & $\mathbf{5 2 7 . 4}$ \\
\cline { 2 - 6 } & meter line & $* 1190$ & $* 2700$ & 3080 & 2230 \\
\cline { 2 - 6 } & $\mathrm{kg} \mathrm{dw} \mathrm{m}{ }^{-1}$ & $* 0.292$ & $* 0.292$ & 0.333 & 0.237 \\
\hline Yield A. esculenta in total & $\mathrm{kg} \mathrm{dw}$ & $\mathbf{0}$ & $\mathbf{4 1 6 . 8}$ & $\mathbf{1 6 5 . 4}$ & $\mathbf{2 8 . 8}$ \\
\cline { 2 - 6 } & meter line & & $\# 500$ & $\# 250$ & $\# 250$ \\
\cline { 2 - 6 } & $\mathrm{kg} \mathrm{dw} \mathrm{m}{ }^{-1}$ & & 0.834 & 0.662 & 0.115 \\
\hline Yield L. digitata in total & $\mathrm{kg} \mathrm{dw}$ & $\mathbf{0}$ & $\mathbf{0}$ & $\mathbf{1 1 3 . 3}$ & $\mathbf{1 0 4 . 6}$ \\
\hline Total harvested yield $\left(\mathrm{Y}_{\text {Total }}\right)$ & $\mathrm{Kkg} \mathrm{dw}$ & & & $\mathbf{3 , 5 1 7 . 0}$ \\
\hline
\end{tabular}

On average, one MACR was harvested within 6.25 working days. Mean handling time per line \pm SD was $10 \pm 5 \mathrm{~min}$ from the first three harvests not including the time used to arrive at the location. The time used for sailing was not included thus comparison between studies is possible even though the cultivation sites are placed at different distance from a harbour.

After introducing modifications on the deck of the harvesting vessel the handling time was reduced to $8 \pm 1 \mathrm{~min}$ in average per line $\pm \mathrm{SD}$ (Table 1). These modifications consisted of a frame that was made from 2-m long PVC pipes, $15 \mathrm{~cm}$ in diameter, standing vertically in a square on the vessel. Between each of the vertical pipes similar horizontal pipes were attached. When harvesting a line, the vessel crane pulled up a line and placed it on top of the frame. Hereafter, the macroalgae was harvested using gravity into storage plastic containers on board. The new harvest method using a frame reduced average working days on one MACR to 3.5 days of harvesting per MACR compared to the 6.25 days (Table 1). The macroalgae biomass was stored in containers on board and in average 2.6 \pm 1.1 (mean $\pm \mathrm{SD}$ ) line would fill one container.

Harvested yield was registered (weighted) after either drying or freezing. This meant that discarded biomass during handling were not registered. Also, the yield left on lines for re-growth was not monitored or used in yield calculation. This must be kept in mind when comparing yield between studies. For each harvest, not all growth lines were cut (Table 1). The excluded lines were either affected by entanglement, had too low yield or were used for other purposes than sale e.g. research.

All the biomass was sold mainly as dried for the food market, and a small quantity as frozen to the cosmetic industry. The sale strategy is based on a "business to business" market implicating that the company Ocean Rainforest $\mathrm{Sp} / \mathrm{f}$ does not carry its own retail brand. 


\subsubsection{Saccharina latissima}

The multiple partial harvesting method was used when S. latissima was harvested and the yield increased at each harvest from the first to the third (Fig. 4). Though, the fourth harvest in July/August 2016 had a lower total yield than the previous. The total harvested biomass of S. latissima from two years was $2688.7 \mathrm{~kg} \mathrm{dw}$. This yield represented harvest of $9200 \mathrm{~m}$ of growth line distributed over four harvests of two MACR's (Table 1). The variation in yield between the different growth lines was large (0.35-7.66 kg dw per line). The average yield per metre of line was determined by field inspections and from total yield per harvest divided by metre of harvested lines. The average yield per metre determined from inspections showed a significant increase between each harvest (One-way ANOVA, $\mathrm{P}=0.0004, \mathrm{n}=5$; Fig. 5). The average yield per metre also increased between the first harvests looking at the harvest yield data (Fig. 5), but it decreased for the fourth one. The macroalgae harvested during 2015 was registered only from the year of harvest and not specified to the harvest turns. Accordingly, the yield of 2015 was divided between the two harvest turns by the number of lines harvested in each turn $\left(1^{\text {st }}\right.$ or $2^{\text {nd }}$ harvest $)$. This number was known due to a registration system used on-board of the vessel of harvested lines (Fig. 4). The average yield per meter in 2015 was accordingly calculated from a total amount harvested biomass divided by total lines harvested in 2015. To improve the yield per meter calculation, the yield was also measured from field inspections before each harvest turn. The yield found from inspections, was hence more accurately describing the yield per meter growth line (Fig 5). 


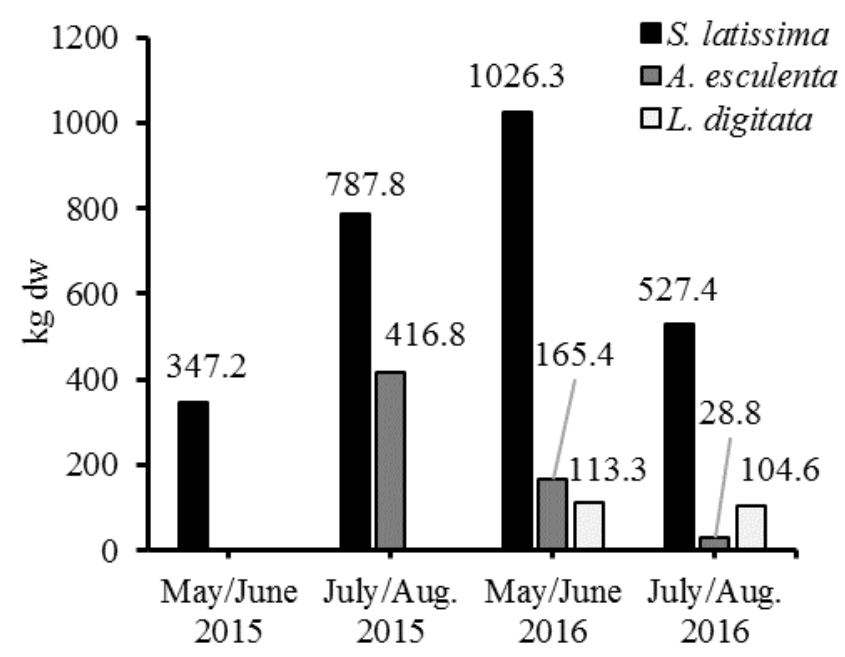

Fig. 4. Total yield from 4200-m Saccharina latissima and 500-m Alaria esculenta-lines in kg dry weight. The biomass was deployed offshore in the Faroe Islands in November 2014, and multiple partial harvested four times without re-seeding of growth lines. In 2016, self-seeded Laminaria digitata had overtaken some lines or part of lines. All three species were harvested, dried or frozen and sold to the food and cosmetic market. The yields represent biomass ready for sale; discarded biomass and biomass left for re-growth were not included.

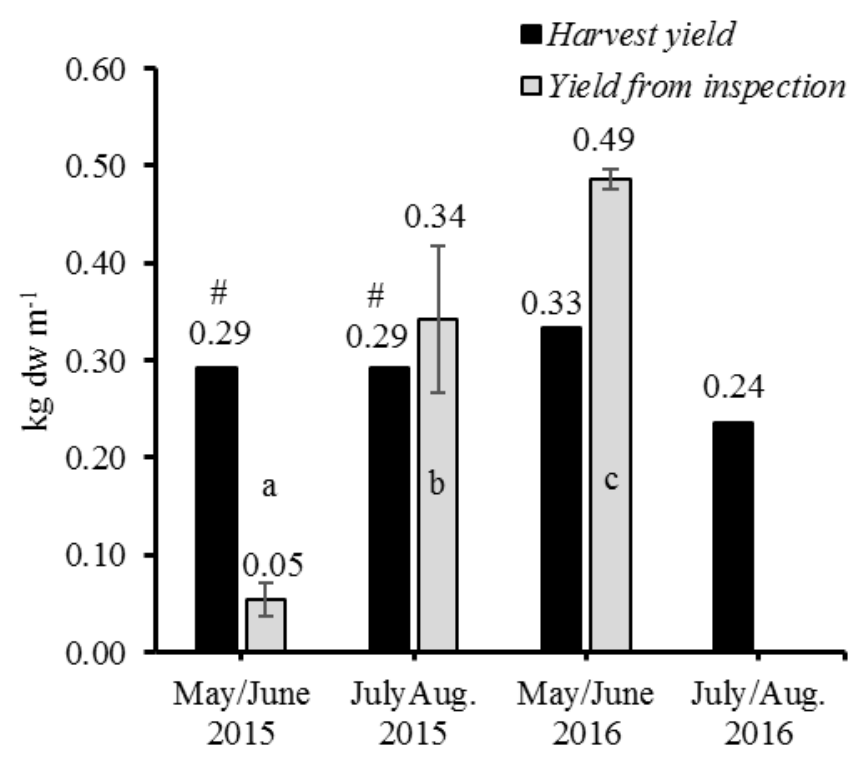

Fig. 5. Average yield of Saccharina latissima in dry weight of one-meter growth line. The biomass was deployed offshore in the Faroe Islands in November 2014, and multiple partial harvested four times without re-seeding of growth lines. Yield per meter was determined either by harvested biomass divided by meter of harvested line (black) or by field inspections ( $\mathrm{n}=5)$, error bars represent standard deviation. Statistical different harvest yields are marked with different letters. Pillars marked with \# was calculated from 
the total 2015-yield and not for each harvest. The yield represents biomass ready for sale and discarded biomass and biomass left for re-growth were not included.

\subsubsection{Alaria esculenta}

Re-growth from multiple partial harvest of cultivated A. esculenta was not previously tested. After deployment in November 2014, A. esculenta was partially harvested the first time in summer 2015. In early spring 2016 re-growth was observed. The re-growth proved that multiple partial harvest of this species is possible. The algae were cut in two different ways (see method and material section 2.4 ) and only lines cut distally of the sporophylls showed re-growth.

First harvest of A. esculenta in July 2015 had a total yield of $417 \mathrm{~kg} \mathrm{dw}$ from 500-m growth line (Fig. 4). This gives an average yield per meter growth line of $0.834 \mathrm{~kg} \mathrm{dw}$ per metre. This yield per meter is not a valid estimation, because self-seeded A. esculenta on S. latissima lines were also harvested and counted together with yield from seeded A. esculenta lines. An A. esculenta seeded line, had approximately a yield of 1-1.5 kg dw with the largest part growing on the first two MBSL (no data shown). For 50 lines, this would result in a yield between $50-75 \mathrm{~kg} \mathrm{dw}$. Hence, the harvested yield of 417 $\mathrm{kg} \mathrm{dw}$ was more than five times the yield one could expect. Consequently, we cannot describe the yield per meter growth line or conduct cost calculations for this species.

The second harvest of $A$. esculenta in May/June 2016 had a yield of $165 \mathrm{~kg}$ dw (Fig. 4), meaning an average yield of $0.33 \mathrm{~kg} \mathrm{dw}$ per meter calculated from $500-\mathrm{m}$ of growth line. This second harvest was crucial for proof of concept of multiple partial harvesting of $A$. esculenta, but not in terms of yield as half of lines were wrongly cut (proximate to the sporophylls) and had, therefore, no biomass. Consequently, a corrected calculation of average yield per metre of growth line was $0.66 \mathrm{~kg}$ dw per metre using harvest from 250-m of growth line. A. esculenta harvested from S. latissima growth lines was continuously used for sale and the yield of A. esculenta from these lines feeds into the total harvested yield and makes the calculation of yield per metre even more invalid. The wrongly cut lines were overtaken by self-seeded $L$. digitata.

The A. esculenta lines showed promising yield for the third harvest in early July 2016, but the biomass had deteriorated significantly one month later when the harvest was planned to take place. Only 
$28.8 \mathrm{~kg} \mathrm{dw}$ were harvested in August 2016 (Fig. 4). This observation advises to conduct the harvesting by mid-July at the latest.

\subsection{Seasonal variation and variation with depth of Saccharina latissima}

Saccharina latissima was harvested when maximal average length was 116.2 \pm 9.4 (mean $\pm \mathrm{SD}) \mathrm{cm}$ and the longest $S$. latissima individual was measured to $329 \mathrm{~cm}$. The highest growth was seen during summer (April-September) and degradation or low growth was seen during winter (November-February; Fig. 6). The seasonal growth pattern was interrupted by two harvests each year during summer months. A growth pattern not disturbed by harvesting was not monitored.

Each meter of growth line had a mean of $64.1 \pm 30.3(\operatorname{mean} \pm \mathrm{SD})$ visible individuals. The large variation in density (Fig. 6) describes an uneven distribution of individuals on the growth lines. This gives room for optimised seeding techniques. There was a large decrease in density after second harvest, which could be due to the multiple partial harvest method. After third harvest, the density was again increasing to 80 individuals per meter. The explanation of this later increase might be self-seeding from wild populations.

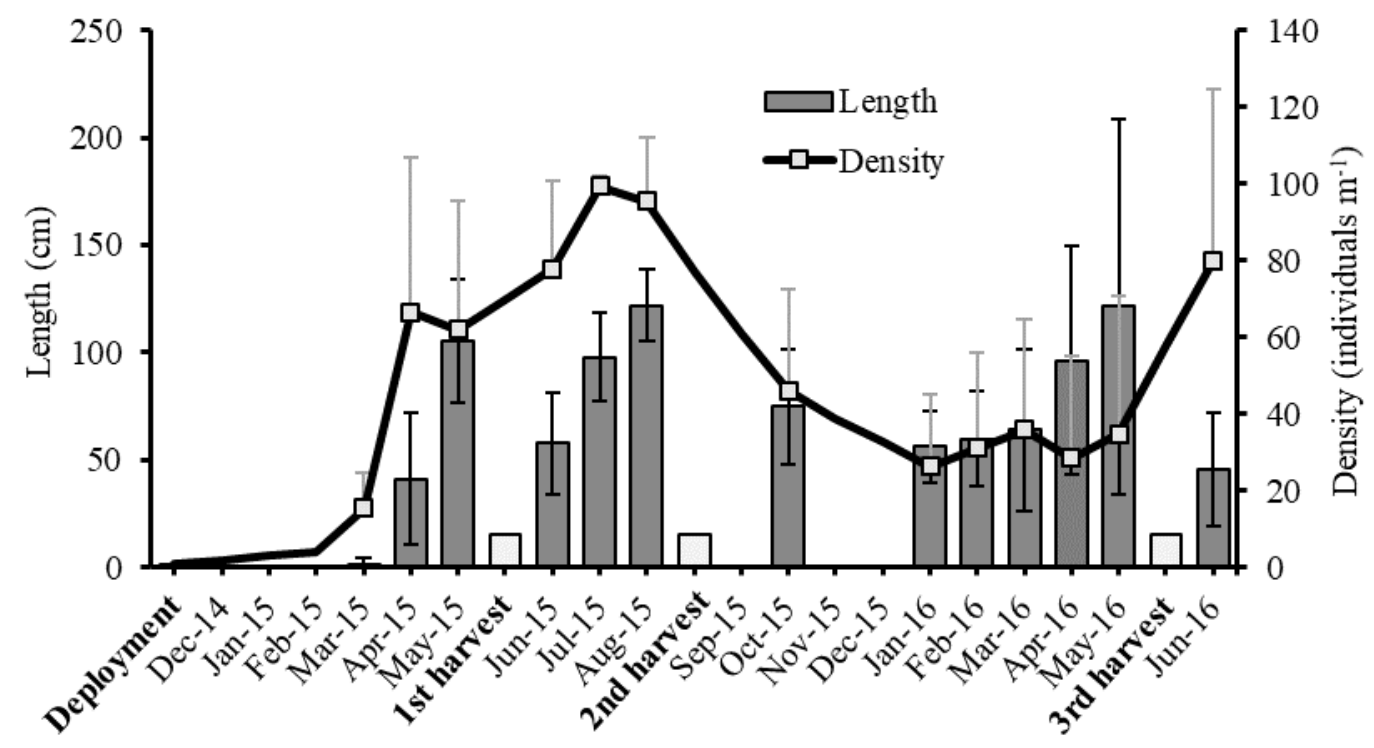

Fig. 6. Growth (average maximal length in $\mathrm{cm} \pm \mathrm{SD}$, black lines) and density (average number of visible individuals per meter + $\mathrm{SD}$, grey lines) of Saccharina latissima $(\mathrm{n}=15)$. The biomass was deployed on 10-m long vertical growth lines offshore in the Faroe Islands in November 2014, monitored monthly, and harvested three times by multiple partial harvesting. The blades were cut 5-15 
$\mathrm{cm}$ above growth line leaving holdfast, stem and part of blade with meristematic tissue. The length after harvest is illustrated as lighter pillars, though not measured.

The growth in depth by length is illustrate in Figure 7. To investigate the maximal cultivation depth below sea level a linear trend line was determined using the monitored growth of S. latissima at five depth intervals: $0-2,2-4,4-6,6-8$ and 8-10 MBSL (Table 2). The linear regression line of the lengthmeasurements showed that S. latissima in May/June 2015 had an increased length with increased depths (slope $1.65 \mathrm{~cm}$ ) and a mean length of the macroalgae of $99.60 \mathrm{~cm}$ at surface level (0 MBSL), probably because no shading occurs when crop was still young (age $<6$ month), and in this way not light limited. The July/August 2015 harvest had a slight decrease in growth (slope $-3.79 \mathrm{~cm}$ ) with decreasing depths and a mean surface length of $125.6 \mathrm{~cm}$. The May/June 2016 harvest had a stronger decrease with depths (slope $-14.48 \mathrm{~cm}$ ) and a larger mean surface length of $208.9 \mathrm{~cm}$. The steeper slope found in May/June 2016 indicates that shading from the proximally algae is more significant for older lines. Hence, the growth during July/August 2015 and May/June 2016 showed light limitation with increased depths.

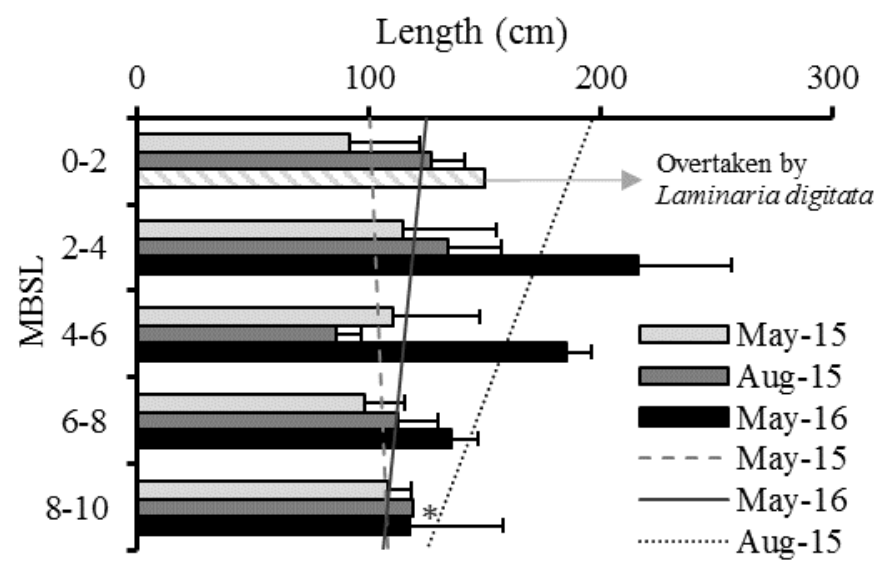

Fig. 7. Mean length in $\mathrm{cm}$ of cultivated Saccharina latissima $(\mathrm{n}=3)$, error bars represent standard deviation. The biomass was deployed on 10-m long vertical growth lines offshore in the Faroe Islands in November 2014, monitored before harvest in May and August 2015 and in May 2016. The length was measured in five different depth intervals 0-2, 2-4, 4-6, 6-8, and 8-10 meters below sea level (MBSL). For each season, a linear trend line was used to show growth trend with decreasing water depths. Pillar marked with * had one replicate. In the second year of cultivation the top meters (0-2 MBSL) were overtaken by Laminaria digitata. 
Table 2. Linear trend lines for cultivated Saccharina latissima deployed offshore in the Faroe Islands in November 2014 using 10 m long vertical growth lines on a Macroalgae Cultivation Rig (MACR). Data for both length and yield measurements was used (Fig. 7 and 8). Mean length/yield at water surface $(\mathrm{x}=0)$ and maximal cultivation depth in meters below sea level (MBSL) were estimated, corresponding to no growth/no biomass $(\mathrm{y}=0)$.

\begin{tabular}{|c|c|c|c|c|c|}
\hline \multicolumn{2}{|c|}{ Saccharina latissima } & \multirow{2}{*}{$\begin{array}{c}\text { May/June } 2015 \\
y=1.65 x+99.60\end{array}$} & \multirow{2}{*}{$\begin{array}{l}\text { July/Aug. } 2015 \\
y=-3.79 x+127.17\end{array}$} & \multirow{2}{*}{$\begin{array}{c}\text { May/June } 2016 \\
y=-14.48 x+204.46\end{array}$} & \multirow{2}{*}{$\begin{array}{r}\text { July/Aug. } 2016 \\
\text { N/A }\end{array}$} \\
\hline \multirow{4}{*}{$\begin{array}{l}5 \\
500 \\
0 \\
0 \\
0\end{array}$} & Linear trend line & & & & \\
\hline & Mean length at surface $(\mathrm{cm})$ & 99.60 & 127.17 & 204.46 & \\
\hline & Max. cultivation depth (MBSL) & & 33.55 & 14.12 & \\
\hline & $\mathrm{R}^{2}$ & 0.0776 & 0.1053 & 0.3348 & \\
\hline \multirow{4}{*}{$\stackrel{\overrightarrow{0}}{\stackrel{\partial}{二}}$} & Linear trend line & N/A & $y=-0.0384 x+0.7444$ & $y=-0.07 x+1.2655$ & N/A \\
\hline & Mean yield at surface $(\mathrm{kg} \mathrm{dw})$ & & 0.7444 & 1.2655 & \\
\hline & Max. cultivation depth (MBSL) & & 19.39 & 18.08 & \\
\hline & $\mathrm{R}^{2}$ & & 0.3988 & 0.4577 & \\
\hline
\end{tabular}

A similar pattern of slightly decreasing yield was seen from field inspection of yield $(\mathrm{kg} \mathrm{dw})$ at different depths (Fig. 8). Before harvest in July/August 2015 ( $2^{\text {nd }}$ harvest) and May/June 2016 ( $3^{\text {rd }}$ harvest), the yield from each meter in general decreased with increased depth below surface, though some depthmeters had higher yield than the meter above. This pattern could generate from few data points, competition between species, or human disturbance (e.g. tangling of lines).

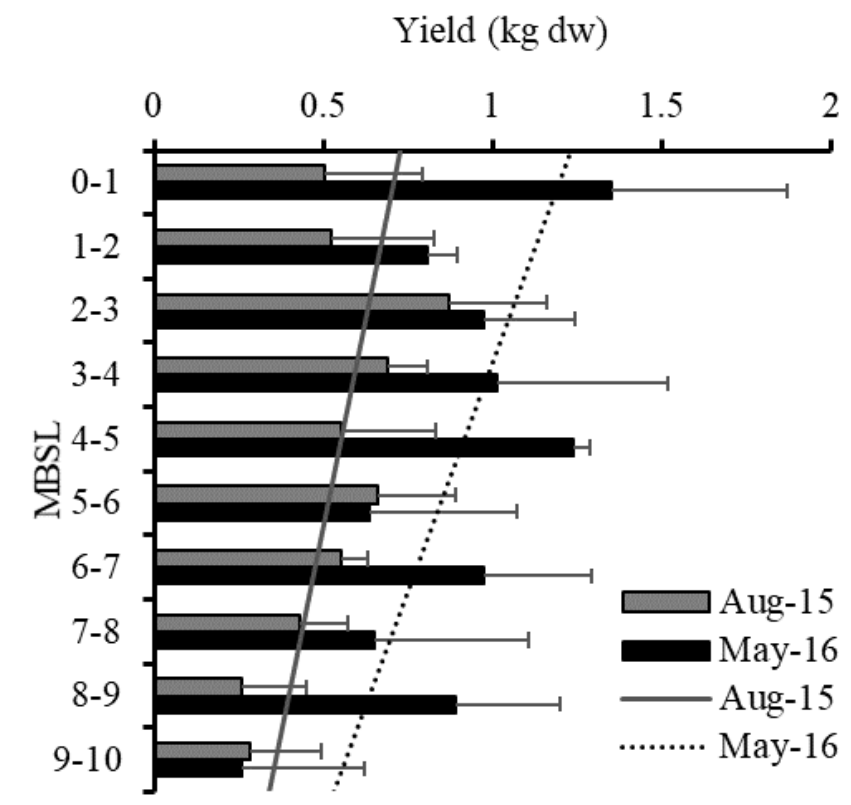


Fig. 8. Measured mean yield in kg dry weight (dw) per meter of Saccharina latissima growth line deployed in November 2014 offshore in the Faroe Islands (Aug-15 n=4, May-16 n=2), error bars represent standard deviation. The yield was monitored during field inspections before harvest in August 2015 and May 2016. The lines were harvested four times without re-seeding of growth lines (no data for yield before harvest in May/June 2015 and July/August 2016). Yield was found for each meter from sea surface to 10 meters below sea level (MBSL). For each season, a linear trend line was used to show growth trend with decreasing water depths.

The seasonal variation and the variation in growth with depths were normally distributed (ShapiroWilk normality test, alpha $=0.05$ ) and the data was, therefore, compared by a parametrical Tukey $\mathrm{t}$-test (Two-way ANOVA, unpaired, alpha $=0.05$; Table 3). The interaction of depth and seasons was found significant $(\mathrm{p}<0.0001)$, indication that seasonal variation (light variation) influences the growth in depth. During summer when it is brighter the macroalgae can grow at deeper water depths than during winter were light is limited.

Table 3. Statistical output of an Ordinary two-way ANOVA, unpaired, Tukey test in GraphPad Prism 7.02. Alpha =0.05.

\begin{tabular}{|l|c|c|c|}
\hline Source of variation & \% of total variation & P value & Significant \\
\hline Interaction (depth x month) (df 36) & 22.93 & $<0.0001$ & Yes \\
\hline Months (df 12) & 39.43 & $<0.0001$ & Yes \\
\hline Depth (df 3) & 1.93 & 0.0258 & Yes \\
\hline
\end{tabular}

The take-home message is that yield decreases with depth as light decreases through the effects of attenuation and shading and the growth season in the Faroe Islands is from April to October where light intensity is highest.

\subsection{Analysis of cost and important scale aspects}

The cost per kg cultivated S. latissima was determined from capital expenditure (CAPEX), operational expenditure (OPEX) and yield (Y) (Table 4). The cost of A. esculenta was not conducted because of 1) unrealistic average yield per metre of growth line, 2) half of the lines were harvested by a wrong method, and 3) a significant deterioration of biomass was seen during July/August 2016. 
Table 4. Cost calculations for cultivated kelp at an offshore and exposed site in the Faroe Islands using the special designed Macroalgae Cultivation Rig (MACR). This case represents one MACR seeded with 2500 meters of Saccharina latissima.

\begin{tabular}{|c|c|c|c|c|c|}
\hline Case: One MACR with Saccharina latissima & Equation & $\begin{array}{c}\text { Base } \\
\text { scenario }\end{array}$ & \multicolumn{3}{|c|}{$\begin{array}{l}\text { Alternative } \\
\text { scenarios }\end{array}$} \\
\hline \multicolumn{6}{|l|}{ Production data } \\
\hline Total meters of growth line & $\mathrm{N}_{\mathrm{GL}} \cdot \mathrm{q}_{\mathrm{rope}}$ & 2,500 & 2,500 & 2,500 & 2,500 \\
\hline Years with same growth lines & & 1 & 1 & 2 & 3 \\
\hline No. of harvests per year & $\mathrm{N}_{\text {harvests }}$ & 1 & 2 & 2 & 2 \\
\hline Total no. of harvests without re-seeding & & 1 & 2 & 4 & 6 \\
\hline Average yield per meter growth line per harvest (kg dw) & G & 0.29 & 0.32 & 0.37 & 0.29 \\
\hline Total cumulated yield per meter growth line ( $\mathrm{kg} \mathrm{dw})$ & & 0.29 & 0.58 & 1.15 & 1.73 \\
\hline Total yield per growth line $/ \mathrm{m}^{2}$ sea surface $(\mathrm{kg} \mathrm{dw})$ & & 2.88 & 5.75 & 11.50 & 17.25 \\
\hline Total yield per MACR / 1 ha ( $\mathrm{kg} \mathrm{dw})$ & & 718.75 & $1,437.50$ & $2,875.00$ & $4,312.50$ \\
\hline Annual yield of harvested biomass ( $\mathrm{kg} \mathrm{dw})$ & Y & 718.75 & $1,437.50$ & $1,437.50$ & $1,437.50$ \\
\hline \multicolumn{6}{|l|}{ Economic data } \\
\hline Cost of rig per year & $\mathrm{TC}_{\mathrm{RIG}} / \mathrm{d}_{\mathrm{RIG}}$ & $€ 6,800$ & $€ 6,800$ & $€ 6,800$ & $€ 6,800$ \\
\hline Cost of growth lines per year $(2500 \mathrm{~m})$ & $\mathrm{TC}_{\mathrm{GL}} / \mathrm{d}_{\mathrm{GL}}$ & $€ 14,900$ & $€ 14,900$ & $€ 7,450$ & $€ 4,967$ \\
\hline Capital expenditure per year & CAPEX & $€ 21,700$ & $€ 21,700$ & $€ 14,250$ & $€ 11,767$ \\
\hline Operating cost per year & OPEX & $€ 4,700$ & $€ 9,400$ & $€ 9,400$ & $€ 9,400$ \\
\hline Total cost per year & & $€ 26,400$ & $€ 31,100$ & $€ 23,650$ & $€ 21,167$ \\
\hline Total cumulated cost per MACR & & $€ 26,400$ & $€ 31,100$ & $€ 47,300$ & $€ 63,500$ \\
\hline \multicolumn{6}{|l|}{ Costs } \\
\hline Cost of rig per kg macroalgae (dw) & & $€ 9.46$ & $€ 4.73$ & $€ 2.37$ & $€ 1.58$ \\
\hline Cost of growth lines per kg macroalgae (dw) & & $€ 20.73$ & $€ 10.37$ & $€ 2.59$ & $€ 1.15$ \\
\hline Operating cost per kg macroalgae (dw) & & $€ 6.54$ & $€ 6.54$ & $€ 6.54$ & $€ 6.54$ \\
\hline Total cost per kg macroalgae (dw) & & $€ 36.73$ & $€ 21.63$ & $€ 11.50$ & $€ 9.27$ \\
\hline
\end{tabular}

The cost calculations for S. latissima were based on the following assumptions: One MACR has a 500-m horizontal fix line with 250 growth lines attached to it, and each growth line is 10 -m long, so that the total growth capacity is 2500 -m of growth lines. The harvesting yield was based on the cultivation from two MACR seeded with S. latissima in November 2014 and harvested during 2015 and 2016. The result of this large-scale cultivation showed that S. latissima was suitable for harvest twice a year.

Based on findings within this survey, the average total cost $\left(\mathrm{TC}_{\mathrm{RIG}}\right)$ of installing one MACR was $€$ 34,000 , and the average total cost $\left(\mathrm{TC}_{\mathrm{GL}}\right)$ of installing the growth lines on one MACR was $€ 14,900$. The 
operational cost (OC) for one MACR was $€ 4,700$ per growth period. Besides the cost of rig and growth lines, CAPEX depended on their durability. The result of cultivating kelp offshore showed that a rig was worn after 5 years at sea $\left(\mathrm{d}_{\mathrm{RIG}}=5\right)$, and the growth lines were depreciated after 3 years $\left(\mathrm{d}_{\mathrm{GL}}=3\right)$.

The base scenario was a single year and one harvest with $0.29 \mathrm{~kg} \mathrm{dw}$ S. latissima per meter. In the base scenario, the growth lines were replaced every year. From the cost per $\mathrm{kg} \mathrm{dw}$ S. latissima, it was seen that the CAPEX was $82 \%$ and OPEX was $18 \%$ of the total cost per kg biomass dw. In the base scenario, cultivation of one $\mathrm{kg}$ S. latissima dw was $€ 36.73$ (Fig. 9).

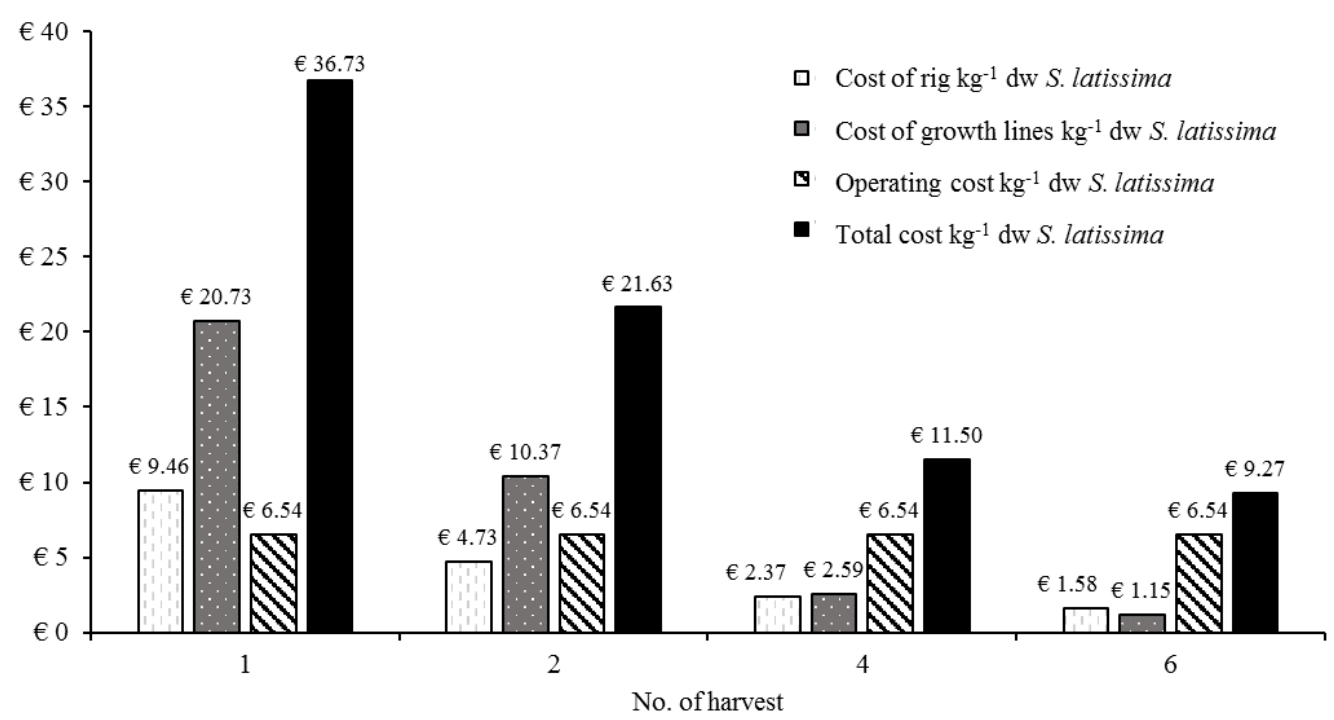

Fig. 9. Cost distribution for different number of harvests from the same growth lines with one (base scenario), two, four or six harvests without re-seeding. The calculation was based on data from two years of Saccharina latissima cultivation offshore in the Faroe Islands using two Macroalgae Cultivation Rig (MACR), a total of $5 \mathrm{~km}$ growth line.

The total cost per $\mathrm{kg}$ dw cultivated biomass decreased from multiple harvesting (alternative scenarios) and the total cost per $\mathrm{kg} \mathrm{dw}$ S. latissima ended at $€ 9.27$. The total cost of rig and growth lines per $\mathrm{kg} \mathrm{dw}$ biomass were declining due to the increase in yield from multiple harvests. However, the operational cost that relied on number of harvests per year and yield remained stable. 
The cost per kg macroalgae was very much dependent on the total number of harvests from growth lines without re-seeding and the yield per metre. In addition, the total cost indicates more room for cost reduction in operational costs compared to the cost of capital expenditures (CAPEX).

\section{Discussion}

\subsection{Survivability of the Macroalgal Cultivation Rig}

The test of the MACR has proved that deployment of installation and growth lines, monitoring, and harvest is possible and easy to handle even though the test site was exposed to waves and placed at a location with a water depth of more than $50 \mathrm{~m}$. Its durability has been successfully determined to five years and the structures tested have survived the physical stress at the cultivation site since 2010. Based on these results, we consider the economic risk related to lost cultivation structures to be low.

The properties of a MACR for large-scale offshore macroalgal cultivation are e.g. the easy handling of the vertical growth lines that enables the production to switch from one species to another between harvests, thus optimising year-round utilisation and commercial performance. The detach of growth lines

will, however, be somewhat challenging due to fouling growing on the knots. This can be prevented, if lines are handled frequently and, in this way, avoiding establishment of severe fouling.

Another advantage of the rig was the flexible structure of the growth lines, as they bend down to a horizontal position under severe weather conditions moving out of the damaging near sea surface zone. The flexibility was also important when boats were sailing through the cultivation area and the lines could bend or move away from the boat without being damaged.

Burg et al. [2] described the importance of a system that enables multiple harvests to reduce production costs, and this was successfully proven by the current work with four partial harvests within 16months. The approach of this work has demonstrated the potential for large-scale macroalgal production at deep-water locations in the North Atlantic region. 


\subsection{Multiple partial harvesting}

A common harvest method for Laminarian species has been to cut the entire blade right at the end of the fast-growing period lasting from January to May in Europe [5,27]. This method requires re-seeding following every harvest, and will, thus, result in higher cost compared to multiple partial harvesting. Several European studies have shown that harvest later than April/May resulted in high fouling, which made the application for food impossible $[5,8,15-18]$. The phenomenon of fouling appears to be coupled to relatively sheltered locations [5]. In contrast to other locations in Europe, the fast growing-period in the Faroe Islands was from March to October, and less fouling occurred as seawater temperature remained low $\left(<11^{\circ} \mathrm{C}\right.$ in summer). Instead of harvesting entire blades followed by re-seeding, this study presented a harvest method that partially cut the blade several times within the life span of the alga lowering the cost per unit macroalgae. Our outcome was most likely related to both physical conditions of the Faroe Islands and the harsh conditions of offshore cultivation: deep-sea location, strong current, and high wave actions (Section 2.1).

Our results showed that at least four harvests were possible without re-seeding $S$. latissima and three harvests for A. esculenta within a period of 16 months, when cut distally to the sporophylls. This has not been proven until now and has major impact on the cost related to seeding, growth lines, and deployment.

The most common harvest method, where the entire blade is cut off, was also used for Saccharina japonica in northern China after a two-years growth period. Zhang et al. [27] presented their average blade length of second-year algae to be $2.7 \mathrm{~m}$, having an average yield per alga of $0.14 \mathrm{~kg} \mathrm{dw}(1.4 \mathrm{~kg} \mathrm{ww})$, and a density of 14-16 individuals per metre of horizontal longline. In our study, S. latissima were harvested when the average maximal length was $116.2 \mathrm{~cm}$ and the sporophyte density was 64 individuals per metre of line (average of all harvests, Fig. 6). The average yield from all depths and from all four harvests was $0.29 \mathrm{~kg} \mathrm{dw}$ per meter (total harvested biomass, Fig. 5). Initially, the method used in the northern China seems to generate a higher yield per metre. On the other hand, did our cultivation have the advantage of four harvests without re-seeding, and the use of vertical cultivation lines, thus expanding the cultivation 
from $2 \mathrm{D}$ to $3 \mathrm{D}$. The question is therefore if higher density, less biomass, 3D cultivation, and a multiple partial harvesting is preferable instead of one harvest of the entire alga in the second year of cultivation?

Zhang et al. [27] had a yield per meter horizontal growth line of $2.21 \mathrm{~kg} \mathrm{dw}(=0.138 \mathrm{~kg} \mathrm{dw}$ per alga * 16 individuals per meter), corresponding to yield per $\mathrm{m}^{2}$ sea surface not including handling space. In our case, using multiple partial harvesting, the yield per $\mathrm{m}^{2}$ sea surface was $11.5 \mathrm{~kg}$ dw (Table 4). Almost five times more than Zhang et al. [27].

Opposite numbers were seen when including handling space as Zhang et al. [27] used 100-meterlong horizontal lines with four meters in between the lines. This was equal to 25 lines in one hectare given in total 2500-m growth line in one ha. The total yield per ha including handling space was therefore 5,527.0 $\mathrm{kg} \mathrm{dw}(=2.21 \mathrm{~kg} \mathrm{dw} * 2500 \mathrm{~m}$ line). In our case with $S$. latissima, the yield per ha from four harvests including handling space was $2,875 \mathrm{~kg} \mathrm{dw}$ (Table 4). Only half the yield of Zhang et al. [27].

This emphasises, that yield per area is very depended on the way it is estimated, and the cultivation method used. The reverse difference, that was seen when comparing yield per $\mathrm{m}^{2}$ vs. yield per ha, must relate to whether space used for handling is included or not. Yet, space-related issues are less important when using an offshore cultivation sites, as these sites are often less utilised.

The Aquaculture Output was estimated as yield per space unit per time $\left(\mathrm{kg}\right.$ dw hat $\left.\mathrm{yr}^{-1}\right)$. This is considered as a universal method for comparison across systems and latitudes. In addition, the distinction between gross and net surface area was introduced, mainly to highlight the difference of factor 40 in expressing yield hat ${ }^{+}$depending of the definition of "utilised" ha in a macroalgae cultivation context. The productivity of real yield from this work (Table 1) was $879.4 \mathrm{~kg} \mathrm{dw}$ hat $\mathrm{yr}^{-1}$ as total biomass harvested was $3,517.6 \mathrm{~kg} d w$ over two years for all three species from MACR 1 and $2(1 \mathrm{MACR}=1 \mathrm{ha})$. The extrapolated annual yield presented in Table 4 was $1,437.5 \mathrm{~kg} \mathrm{dw} \mathrm{ha}^{-1} \mathrm{yr}^{-1}$ based on average yield per meter line. The productivity potential of the system used in the Faroe Islands will properly improve over time and does not yet reflect the large scale commercial potential. However, these data are one examples of real world outputs from offshore cultivation and provide a reality check as to what can be achieved in high latitude areas of production. 
In theory, the multiple partial harvesting method should reduce the growth rate, because Laminarian species grow the new blade from the meristem between the stipe and the blade using photosynthetic translocation from the old part of the blade to the meristematic sink [45]. Unfortunately, no lines were left as control lines (not harvested) and the effect on growth and yield of multiple partial harvesting still need more investigation.

Multiple partial harvesting was shown suitable in the Faroe Islands, and this can be explained by lower seawater temperatures, and accordingly lower fouling rates. Lower fouling rates, enabled the algae to grow throughout the summer and for several years. Another explanation could be that nitrate was available for macroalgal growth throughout the year in the Faroe Islands [46], and thus the algae could regrow even without the older blade part. Nitrate levels have been measured by the Marine Research Institute on the Faroese continental shelf since 1995 [47], and only three times was the nitrate concentration observed to drop below $3 \mu \mathrm{M}$, which is the limiting level for S. latissima. The geographical location of the cultivation site at the mouth of a fjord makes the site more comparable to continental shelf conditions than to fjord conditions.

In addition, to favourable nitrate conditions for macroalgal growth, temperature and salinity were extremely stable throughout a year, and based on Gaard et al. [47] the light-compensation depth measured in a Faroese fjord was below $10 \mathrm{~m}$ depth throughout the year except in December and January, where it could be as shallow as $5 \mathrm{~m}$ depth. The $10 \mathrm{~m}$ long growth lines used in this work are thus above the compensation depth nearly throughout the entire year.

Zhang et al. [27] reported that approximately $90 \%$ of the annual blade production was lost due to erosion at the blade tip. A continual multiple partial harvesting could possibly decrease the loss of biomass because the blades were cut when they were still relatively young and with fresh cell tissue. This might also decrease the level of biofouling on the blades because the fouled blade portions infested in spring are removed in July, and therefore not spread to blade tissue newly grown in the interval between July and October. 
In addition, the conditions of the offshore cultivation site with high current, large water column, and longer distance to naturally established populations could be the explanation of a very low biofouling density covering the macroalgae.

In comparison with cultivation trials in the North Sea [2,5], we found it possible to cultivate $S$. latissima also through summer and that we could keep the same seeding material over more years. Our findings support the observations of Wegeberg et el. [28] who emphasized the high potential for macroalgal cultivation in the Faroe Islands due to a relatively large ocean area and stable nitrate and temperature levels throughout the year.

Mols-Mortensen et al. [29] found that the quality of cultivated S. latissima measured by protein concentration and essential amino acid score was significantly higher in May and June compared to July and August in the Faroe Islands. Other studies have equally shown seasonal variation in the biochemical composition of macroalgae [8,48-49]. Cultivated S. latissima biomass that is harvested at different times of the year will thus be expected to show seasonal variation in between batches. This is important to be aware of when harvesting several times during a year.

\subsection{Optimised yield}

Although the MACR has provided promising results, there is still a need to improve the rig, especially to reduce the handling in relation to harvesting and operational cost. To increase the total production per area sea surface, future constructions could be improved by lengthening the growth lines e.g. to $20 \mathrm{~m}$. This would decrease the production cost per meter of cultivated macroalgae and increase the yield per $\mathrm{m}^{2}$ sea surface. In the inner Danish seawaters, S. latissima can in theory grow down to 12-14 MBSL during the summer period at sites with low light attenuation [50]. In comparison, our findings suggest a maximal cultivation depth of 18-19 m (Table 3). But, the yield at these lower meters is not yet known, and the optimal cultivation depth (length of growth lines) is currently being tested in situ in the Faroe Islands. The final maximal cultivation depth will depend on yield per lowest meter and total cost per meter growth line. The significant variation in growth during different months and at different depths depends on the amount of 
light throughout the year and the transmittance of light in the water column. Nutrient level and seawater temperature are not likely to play a major role determining seasonal growth performance as these are predominantly constant year-round and seawater masses are fully mixed at the cultivation site. Two factors complicate the calculation of expected yields at different depths. Firstly, cultivated macroalgae will have a shading effect on the underlaying alga and secondly, growth lines will move with the current. As a result, it is necessary to conduct a tentative cost-benefit analyses of cultivation in deeper depths or establish in situ experiments. The linear trend lines (Table 2$)$ showed very low correlation-coefficients $\left(\mathrm{R}^{2}<0.45\right)$ for all harvests. The variation with depth was better described by a 2-grade polynomic trend line (data not shown), because the lines had the lowest yield near surface and at the lowest depths (8-10 MBSL). The decrease of yield with lower depths was proposed by the attenuation of light through water column [50]. The lower yield in the first meters below sea level, was most likely due to interspecific competition between species, as from A. esculenta and L. digitata which was often found at this upper part of the lines. These two species had thus a better survival at more wave exposed sites, and with occasional high light intensities.

The results show a large variation in the yield between the different growth lines, which is a challenge for large-scale production. One way of improving the production is to increase yield per meter growth line. Uniform sporophyte density and growth are considered important to obtain a higher yield and more stable supply to the market. A way to optimize yield is to understand the seasonal variation in growth and use this knowledge in determining the optimal timing for deployment and harvesting. Selective breeding will also have a major role in optimising yield as seen from Asian macroalgal cultivation and in the agriculture sector. This is therefore an important topic in future research.

Also, the yield and quality are very much dependent on low levels of fouling, and grazing animals. This study demonstrated a very clean biomass of primary food quality, although there was more fouling during the late summer harvest than spring harvest. A mean reduction in expected biomass for third harvest of $A$. esculenta could be due to grazing animals. Understanding the behavior of the grazing animals living in offshore artificial macroalgal fields is therefore of paramount importance. Nevertheless, the offshore cultivation site is considered to contribute towards the low amount of fouling. Our findings support the theory of Arrontes [51], Mols-Mortensen et al. [29], and Bruhn et al. [5] who recommend avoiding sheltered 
cultivation areas and instead benefit from more open sea areas with stronger currents, lower nutrient levels, and lower and more stable temperatures.

Finally, the business case will be improved by utilizing $100 \%$ of the harvested biomass. In such case discarded macroalgae will be used in a zero-waste production and sold as fertilizer, feed and/or be used in the extraction of high value products e.g. fucoidan.

\subsection{Cost of offshore cultivation}

The cost calculation was based on empirical data generated through the harvest periods 2015 and 2016. From the cost calculations, it was clear that the variable yield ( $\mathrm{dw}$ per meter of growth line per harvest) had a major influence on the overall economic performance expressed in cost per kg macroalgae. However, the most important finding was the impact of the multiannual harvest on the economic performance, with a $75 \%$ reduction of cost per $\mathrm{kg}$ cultivated $S$. latissima in the maximum cultivation scenario with six harvests per growth line deployed, compared to one harvest in the base scenario. This means that the capital expenditures (CAPEX) per kg was reduced by factor 2-6 depending on the number of harvests made from the same growth lines without re-seeding. This was a result of the very suitable physical conditions in the Faroe Islands combined with offshore cultivation to reduce fouling. In addition, in a large-scale deployment scenario the CAPEX will be reduced as a function of economy of scale related to equipment production and installation.

There was also room for improvements in the operational cost per year (OPEX). The need for innovation in relation to the operations was evident as it remains equal for the various scenarios. The main OPEX cost reduction driver will be increased mechanisation of seeding and harvesting processes. Furthermore, increased know-how through years of operation will reduce expenditures related to inspections of cultivation lines. In addition, an overall improvement of harvested yield per metre or area, e.g. because of a selective breeding program, will reduce the cost per $\mathrm{kg}$ of the harvested biomass.

In addition, continuous innovation and climbing learning curves are expected to improve operational efficiency. The improved harvest system using a frame on board to hold the lines was first step to optimize 
harvesting, however a bigger step will be to develop mechanical harvest equipment and thereby reduce the labour required for harvesting from e.g. three persons to one or two persons. It is important to bear in mind that the revenue will also be influenced by quality of the macroalgae, both fouling and biochemical composition, which varies with season.

It is expected that the cost will be reduced by economy of scale in large-scale cultivation scenario both in terms of cost of MACR's and in terms of quantity tonnes biomass processed, but the scaling factor will need further investigation. Finally, reducing operating costs by economy of scale in large-scale cultivation scenario, the multiple partial harvesting method, and increasing yield per meter is vital for the commercial viability of offshore macroalgal cultivation.

\section{Conclusion}

The Macroalgae Cultivation Rig was proven successful for the conditions found at the cultivation location in Funningsfjørður. Next step will be to test the system in another location with similar conditions. The harvest method multiple partial harvesting was proven suitable for Saccharina latissima and Alaria esculenta, and the method increases the yield per meter growth line in oceans with stable seawater temperature and high nutrient level as in the Faroe Islands. However, to improve the economic feasibility of macroalgal cultivation in the Western world, further efforts are needed both in relation to increasing the yield and lowering operational costs. Future studies should focus on increasing the yield measured as the biomass produced per meter of seeded line. Optimizing seeding methods, selective breeding, and longer growth lines (expanding cultivation depth) can all contribute to increased yields, and more research is needed on how to optimize the production in relation to those parameters. The cultivation of macroalgae also requires innovation in relation to lowering the operational costs. In that respect, an important area of focus should be the development of mechanised harvesting methods. 


\section{Acknowledgements}

The authors are grateful for the financial support from Nordic Innovation in 2015 through grant number Mar-14324 (MacroValue) and by NORA-Nordatlantisk Samarbejde in 2013 through grant number 510-102 (MacroBiotech). The author Urd Grandorf Bak has received research grants from Innovation fund Denmark for an Industrial Ph.D. education (2016-2019).

The authors would like to thank Professor Matthew Dring for his constructive input and comments on the first manuscript version. Furthermore, the authors would like to acknowledge the important work conducted by Gilli Trónd and Rúni Joensen as concept inventors and designers of the offshore cultivation system MACR. Last, but not less important, the authors would like to thank all their colleagues at Ocean Rainforest Sp/f, who have helped make this research possible. 


\section{References}

[1] A.H. Buschmann, et al., Seaweed production: overview of the global state of exploitation, farming and emerging research activity, European Journal of Phycology, 52:4 (2017) 391-406.

[2] S.W.K. van den Burg, et al., The economic feasibility of seaweed production in the North Sea. Aquaculture Economics \& Management 20:3 (2016) 235-252.

[3] F. Fernand, et al., Offshore macroalgae biomass for bioenergy production: Environmental aspects, technological achievements and challenges, Renew. Sustainable Energy Rev. 75 (2017) 35-45.

[4] S. Kraan, In: Seaweed in Health and Disease Prevention, Chapter 6 - Seaweed and Alcohol: Biofuel or Booze?, Elsevier Inc. (2016) 169-184.

[5] A. Bruhn, et al., Impact of environmental conditions on biomass yield, quality, and bio-mitigation capacity of Saccharina latissima, Aquaculture Environment Interactions 8 (2016) 619-636.

[6] B. Charrier, et al., Furthering knowledge of seaweed growth and development to facilitate sustainable aquaculture, A viewpoint, New Phycologist (2017).

[7] D.P. Chynoweth, Report: Review of Biomethane From Marine Biomass. Review of History, Results and Conclusions of the "US Marine Biomass Energy Program" (1968-1990). Marine Agronomy (2002).

[8] G.S. Marinho, S.L. Holdt, I. Angelidaki, Seasonal variations in the amino acid profile and protein nutritional value of Saccharina latissima cultivated in a commercial IMTA system, J. Appl. Phycol. 27 (2015) 1991-2000. 
[9] M. Troell, et al., Ecological engineering in aquaculture: use of seaweeds for removing nutrients from intensive mariculture, J. Appl. Phycol. 11 (1999) 89-97.

[10] A. Jensen, Present and future needs for algae and algal products, Hydrobiologia 260/261 (1993) 1523.

[11] E.A. Titlyanov, T.V. Titlyanova, Seaweed Cultivation: Methods and Problems, Russ. J. Mar. Biol. $36(2010) 227-242$.

[12] FAO - Food and Agriculture Organization of the United Nations Statistics Division, Global Aquaculture Production 1950-2015, Retrieved April 26, 2017. Available from: http://www.fao.org/fishery/statistics/global-aquaculture-production/query/en.

[13] D. Valderrama, et al., The Economics of Kappaphycus Seaweed Cultivation in Developing Countries: A Comparative Analysis of Farming Systems. Aquaculture Economics \& Management 19:2 (2015) 251277.

[14] S. Zuniga-Jara, M.C. Marín-Riffo, C. Bulboa-Contador, Bioeconomic analysis of giant kelp Macrocystis pyrifera cultivation (Laminariales; Phaeophyceae) in northern Chile, J. Appl. Phycol. 28 (2016) 405-416.

[15] M.M. Nielsen, Cultivation of kelps for energy, fish feed and bioremediation. PhD thesis, Aarhus University, Denmark (2015).

[16] A. Handå, et al., Seasonal- and depth-dependent growth of cultivated kelp (Saccharina latissima) in close proximity to salmon (Salmo salar) aquaculture in Norway, Aquaculture 414-415 (2013) 191-201. 
[17] C. Peteiro, O. Freire, Epiphytism on blades of the edible kelps Undaria pinnatifida and Saccharina latissima farmed under different abiotic conditions. J. World Aquacult. Soc. 44 (2013) 706-715.

[18] S. Wegeberg, Cultivation of kelp species in the Limfjord, Denmark, Department of Biology, Copenhagen University, Denmark (2010).

[19] W.W. McNeary, L.E. Erickson, Sustainable Management of Algae in Eutrophic Ecosystems, J. Environ. Prot. 4 (2013) 11A.

[20] O.O. Sulaiman, et al., Mooring analysis for very large offshore aquaculture ocean plantation floating structure. Ocean Coast Manag. 80 (2013) 80-88.

[21] X. Fei, Solving the coastal eutrophication problem by large-scale seaweed cultivation, Hydrobiologia 512 (2004) 145-151.

[22] J. Ryan, Farming the deep blue, Report, September 2004.

[23] K.T. Bird, P.H. Benson, Seaweed Cultivation for Renewable Resources, Elsevier Science Pub. Co. Inc., New York, 1987.

[24] A.B. Flowers, K.T. Bird, Methane Production from Seaweeds, In: I. Akatsuga (ed.): Introduction to Applied Phycology. SPB Academic Publishers bv, The Hague, 575-587, 1990.

[25] B.H. Buck, C.M. Buchholz, The offshore-ring: A new system design for the open ocean aquaculture of macroalgae, J. Appl. Phycol. 16 (2004) 355-368. 
[26] C. Peteiro, Ó. Freire, Offshore cultivation methods affects blade features of the edible seaweed Saccharina latissima in a bay of Galicia, Northwest Spain, Russ. J. Mar. Biol. 37(4) (2011) 319-323.

[27] J. Zhang, et al., Growth and loss of mariculture kelp Saccharina japonica in Sungo Bay, China, J. appl. Phycol. 24 (2012) 1209-1216.

[28] S. Wegeberg, A. Mols-Mortensen, K. Engell-Sørensen, Sustainable production and utilization of marine resources in the Arctic, fish and seaweed (SPUMA), Scientific report from DCE - The National Center for Environment and Energy 82, Denmark, 2013.

[29] A. Mols-Mortensen, E. á Geilini Ortind, C. Jacobsen, S.L. Holdt, Variation in growth, yield and protein concentration in Saccharina latissima (Laminariales, Phaeophyceae) cultivated with different wave and current exposures in the Faroe Islands, J. Appl. Phycol., 22nd International Seaweed Symposium, Copenhagen, 2017.

[30] C. Peteiro, Ó. Freire, Effect of Outplanting Time on the Commercial Cultivation of the Kelp Laminaria saccharina at the Southern Limit in the Atlantic Coast (N.W. Spain), Chin. J. Oceanol. Limnol., 27:1 (2009) 54-60.

[31] J. Cremades, et al., Nuevo Método Para el Cultivo Industrial de Laminaria saccharina (Laminariales, Phaeophyta) en las Costas Gallegas in XI Congreso Nacional de Acuicultura, Cerviño Eiroa, A., Guerra Díaz, A. and Pérez Acosta, C., Eds., Vigo, Spain: Consellería de Pesca e Asuntos Marítimos, Xunta de Galicia (2007) 559-562.

[32] C. Peteiro, J.M. Salinas, Ó. Freire, C. Fuertes, Cultivation of the Autoctonous Seaweed Laminaria saccharina off the Galician Coast (NW): Production and Features of the Sporophytes for an Annual and Biennial Harvest, Thalassas 22:1 (2006) 45-52. 
[33] B.H. Buck, C.M. Buchholz, Response of offshore cultivated Laminaria saccharina to hydrodynamic forcing in the North Sea, Aquaculture 250 (2005) 674-691.

[34] V.A. Chugaynova, S.P. Gorennikov, Mariculture of Laminaria saccharina in the White Sea, Hydrobiol. J. 32:2 (1996) 63-67.

[35] J.M. Kain (Jones), T.J. Holt, C.P. Dawes, European Laminariales and their Cultivation in Economically important plants of the Atlantic: their biology and cultivation, Yarish, C., Penniman, C.A. and Van Petten, P., Eds., Groton: Connecticut Sea Grant College Program, University of Connecticut (1990) 95-111.

[36] G. Bruntse, T.E. Lein, R. Nielsen, Marine benthic algae and invertebrate communities from the shallow waters of the Faroe Islands, Kaldbak Marine Biological Laboratory, 1999.

[37] Landsverk, Ministry of the Interior, Tórshavn, the Faroe Island. Retrieved November 13, 2013. Available from: http://www.landsverk.fo/.

[38] G. á Norði, Ø. Patursson, Influence of waves and current speed on resuspension of fish farm waste: Case study in Funningsfjørður, Faroe Islands, Fiskaaling - Aquaculture research station of the Faroes, 2012.

[39] B.A. Niclassen, K. Simonsen, High resolution wave climate of the Faroe Islands, Technical Report, 2012.

[40] K.M.H. Larsen, B. Hansen, H. Svendsen, Faroe Shelf Water, Continental Shelf Research 28 (2008) $1754-1768$. 
[41] S.K. Eliasen, B. Hansen, Light in Faroese Waters, Technical Report No.: 03-01, The Faroese Fisheries Laboratory, Thorshavn, Faroe Islands, 2003.

[42] M. Edwards, L. Watson, Cultivating Laminaria digitata, Irish Sea Fisheries Board, Aquaculture Explained 26 (2011) 72.

[43] FAO - Food and Agriculture Organization of the United Nations Statistics Division, Handbook of Eucheuma Seaweed, 4. Harvesting and selling seaweed: "What care is required after seaweed is harvested?", $\quad$ Retrieved $\quad$ March $15, \quad$ 2018, Available from: http://www.fao.org/docrep/field/003/AC287E/AC287E04.htm

[44] Research Gate, Doctor Thierry Chopin added answer to the discussion: "What is the water content in the seaweed tissue?”, 2015, Retrieved March 15, 2018. Available from: https://www.researchgate.net/post/What_is_the_water_content_in_the_seaweed_tissue

[45] I. Bartsch, et al., The genus Laminaria sensu lato, Eur. J. Phycol. 43 (2008) 1-86.

[46] Havstovan, Faroe Marine Research Institute, the Faroe Island, Retrieved October 12, 2015. Available from: http://www.hav.fo/.

[47] E. Gaard, G. á Norði, K. Simonsen, Environmental effects on phytoplankton production in northeast Atlantic fjord, Faore Islands, J. Plankton Res. 33 (2011) 947-959.

[48] A. Bruhn, et al., Crude fucoidan content in two North Atlantic kelp species, Saccharina latissima and Laminaria digitata—seasonal variation and impact of environmental factors, J. Appl. Phycol. (2017) 29:3121-3137. 
[49] M.M. Nielsen, et al., Growth dynamics of Saccharina latissima (Laminariales, Phaeophyceae) in Aarhus Bay, Denmark, and along the species' distribution range, Mar. Biol. (2014) 161:2011-2022.

[50] U.G. Bak, Suitable cultivation areas for Palmaria palmata (Rhodophyta) and Saccharina latissima (Phaeophyceae) in the inner Danish waters in relation to variations in light, temperature and salinity, Master thesis, Roskilde University, Denmark, 2014.

[51] J. Arrontes, Composition, Distribution on Host, and Seasonality of Epiphytes on Three Intertidal Algae, Bot. Mar. 33 (1990) 205-211. 


\section{HIGHLIGHTS}

- This work has demonstrated that large-scale Kkelp cultivation is possible using multiple partial-cutting in the Faroe Islands and highlighted the need for further innovation to lower the cost per unit seaweed.

- The two Keklp species Saccharina latissima and Alaria esculenta are suitable for multiple partial harvest (non-destructive) when cultivated in the Faroe Islands offshore. Lines seeded with S. latissima can be harvested two times a year for three years without reseeding.

- The total cost per $\mathrm{kg}(\mathrm{ww})$ cultivated Saccharina latissima was decreasing when number of possible harvests without re-seeding increased (from $€ 3-6.7$ to $€ \theta .9 .3$ ).

- The tested macroalgal cultivation rig (MACR) is suitable for seaweed cultivation at wave exposed and deep-water locations (up to 4-m significant wave height and $>50 \mathrm{~m}$ depth). 


\title{
Abstract
}

The current work aimed to develop a cultivation method for macroalgae that can be applicable and economically profitable in the Atlantic Ocean. An offshore long-line macroalgal cultivation rig was designed by Ocean Rainforest Sp/f, tested in the Faroe Islands from 2010, and found suitable for cultivation in exposed and deep-water locations (water depth $>50 \mathrm{~m}$ ). The economic risk related to lost cultivation structures was hereafter considered to be low. Saccharina latissima and Alaria esculenta were cultivated in commercial scale (5 km of growth lines). A high cost of seeding material and cost of deployment was reduced by testing multiple partial harvesting. Four non-destructive harvests were carried out in a two-year growth period without re-seeding of lines. In total, 3.2 tonnes dry weight (dw) biomass was harvested and sold to customers within the food and cosmetic industries. The productivity was $1,437.5 \mathrm{~kg} \mathrm{dw} \mathrm{ha}^{-1} \mathrm{yr}^{-1}$ (including handling space). The 10-meter vertical growth lines had an average yield of $0.29 \mathrm{~kg} \mathrm{dw} \mathrm{m}^{-1}$ per harvest and four partial harvests were made over a 2-year period. An economic analysis showing the cost structure of important aspects of offshore macroalgae cultivation was conducted. The total cost per $\mathrm{kg} \mathrm{dw}$ of cultivated S. latissima decreased when the number of possible harvests without re-seeding was increased (from $€ 36.73$ to $€ 9.27$ ). This work has demonstrated that large-scale kelp cultivation is possible using multiple partial harvesting in the Faroe Islands, and highlighted the need for further innovation to lower the cost per unit macroalgal produced.

\section{Keywords}

Offshore cultivation; Economic; Saccharina latissima; Alaria esculenta; The Faroe Islands; Multiple partial harvesting

\begin{abstract}
Abbreviations
MACR, MacroAlgae Cultivation Rig; MBSL, meter below sea level; dw, dry weight; ww, wet weight; SD, standard deviation; ha, hectare
\end{abstract}




\section{Introduction}

The need for food is increasing globally and, therefore, the efficient use of natural resources is increasingly vital. Most land areas are already utilized for the conventional agriculture of terrestrial plants. However, the oceans, that cover more than $70 \%$ of the planet, potentially offer solutions for future sustainable large-scale biomass production. The use of macroalgae (seaweeds) has a long history, as does the cultivation at sea of a relatively small group of macroalgal species [1]. In North America and in Europe, macroalgae are a relatively underexploited resource, though they are the subject of an increasing interest for their potential as human food, animal feed, cosmetics, bioactive components, and biofuel [2-8]. The interest in macroalgal cultivation is driven by a market demand [1-2,8] and because of environmental concerns related to wild harvest of macroalgae [9-11].

Cultivation of macroalgae has important environmental benefits compared to harvesting wild populations. Instead of damaging natural ecosystems, new artificial marine forests are established with similar environmental functions as a nursery habitat for juvenile fish and as a food source for animals. The cultivated macroalgal biomass bioremediates nutrients and carbon $\left(\mathrm{CO}_{2}\right)$ from the surrounding environment as biomass [3,9-10]. There is therefore an ecological benefit to be gained from the cultivation of macroalgae.

The European macroalgal industry currently relies on wild harvesting, unlike Asian producers that mainly rely on cultivation. In 2015, Asia produced 27 million tonnes wet weight (ww) macroalgal biomass, corresponding to approximately 2.7 million tonnes dry weight (dw), whereas the yield in Europe was only a few hundred tonnes dw [12]. The cultivation methods developed in Asia through centuries are not easily applicable to the western countries. The reason is that the cultivation methods that are used are labour intensive, and the methods are not proven to be profitable in the Western world [2,13]. Zuniga-Jara et al. [14] made a feasibility study of offshore commercial kelp cultivation in Chile, and concluded that it was not profitable, as the sale of the biomass was unable to cover the investment costs or the operation costs.

To reduce production cost, Burg et al. [2] described the importance of developing a cultivation system that enables multiple partial harvests. Furthermore, biofouling seems to be a major issue for cultivation in 
Europe $[8,15-18]$, and the phenomenon appears to be coupled to relatively sheltered locations preventing the use of multiple partial harvesting [5,19]. Offshore cultivation, therefore, seems to be vital for a profitable macroalgal industry [5,20-21].

Offshore cultivation is defined as "the execution of activities in sites that are subject to ocean waves", which is linked to distance from shore or lack of shelter from topographical features such as islands or headlands that can mitigate the force of ocean and wind-generated waves and sites with significant wave heights of two meters or above [22].

Producing macroalgae offshore is thus promising in terms of market potential and sustainability, but an extremely challenging endeavour [2-4,7,20,23-27].

Relatively few macroalgal species have been utilized for production [1], nevertheless, kelps have been exposed to some of the first pioneer cultivation trials in North America and in Europe. The two kelp species Saccharina latissima (Linnaeus) Lane, Mayes, Druehl and Saunders, commonly known as "sugar kombu" or "sugar kelp", and Alaria esculenta (Linnaeus) Greville, with the common name "winged kelp", have attracted commercial interest for human consumption as sea-vegetables $[8,17,26]$. S. latissima grows on the lower shore in semi-exposed areas, whereas A. esculenta is very tolerant to more severe wave exposure. Both algae are distributed along the northern Atlantic coasts and in Arctic areas. S. latissima is also found along the northern Pacific coasts and is distributed in oceans with higher temperatures and lower salinities than A. esculenta. The cultivation techniques are well developed for both species, and especially S. latissima is described as having good potential for commercial-scale cultivation in Europe and in the North Atlantic $[2,28]$.

During the past decades, several macroalgal cultivation trials have been conducted in the Atlantic Ocean in particularly using S. latissima [26,28-35]. However, none of these cultivation trials have resulted in large-scale profitable cultivation [2].

This paper describes the work of several years innovative large-scale kelp cultivation in the Faroe Islands, documenting the use of a new concept for offshore cultivation installation: the Macroalgal Cultivation Rig (MACR). Also, the effect on economics of multiple partial harvesting of S. latissima and A. esculenta was described for the first time. The cultivation data reflects the large variation in growth and 


\section{Material and Methods}

\subsection{Cultivation site and environmental conditions}

The macroalgal cultivation site was located at the mouth of Funningsfjørður in the Faroe Islands $\left(62.3030^{\circ} \mathrm{N}, 6.9267^{\circ} \mathrm{W}\right.$; Fig. 1). The Faroe Islands are an archipelago situated in the Northeast Atlantic Ocean. The site had a water depth of 50-70 m, was exposed to currents of $15-25 \mathrm{~cm} \mathrm{~s}^{-1}$ and was characterized as an exposed area with occasional significant wave heights of 3-6 m [36-39]. The North Atlantic Current, which originates from the warm Gulf Stream, runs past the Faroe Islands and brings warm currents to the area, providing a relatively stable seawater temperature ranging from 6 to $11^{\circ} \mathrm{C}$ during the year [40]. The salinity was very stable at $35.0-35.2$ [40]. Contrary to salinity, the irradiance and day length varied substantially through the year. Irradiance measured at land surface varied from less than $50 \mu \mathrm{E} \mathrm{m} \mathrm{m}^{-2} \mathrm{~s}^{-1}$ in November to February and up to $300 \mu \mathrm{E} \mathrm{m}^{-2} \mathrm{~s}^{-1}$ in average during May [41]. There was a large drop in irradiance when penetrating sea surface due to reflection. In the seawater column light can penetrate down to $30-50$ meter below sea level (MBSL), though at these depths the irradiance was very low $\left(<10 \mu \mathrm{E} \mathrm{m}{ }^{-2}\right.$ $\left.\mathrm{s}^{-1}\right)$. There was a linear relationship between the phytoplankton concentration and the attenuation coefficient, which varied between 0.05 and $0.3 \mathrm{~m}^{-1}$ [41] 


\subsection{Cultivation system}

The Macroalgae Cultivation Rig (MACR) developed by the company Ocean Rainforest Sp/f was designed to withstand the conditions of the North Atlantic Ocean (Fig. 2). The MACR was constructed using lightweight and robust equipment. None of the parts were specially designed, as all equipment was bought from a local manufacturer selling fishing gear, aquaculture equipment, and equipment to the offshore industry.

The design consisted of a 500-m long polysteel fix line (30 $\mathrm{mm}$ in diameter) suspended horizontally at 10 MBSL (C, Fig. 2). Two main surface floats (D, Fig. 2) were connected to the fix line and $40 \%$ submerged in a static state. The mooring system consisted of four 120-m anchor lines, which were attached to the fix line and anchored to the seafloor with 1-1.5 tonne steel anchors (E, Fig. 2). One MACR occupied a sea surface area of 1 ha (one MACR has a nominal width of $10 \mathrm{~m}$ on each side of the fix line). The rig had approximately 250 growth lines (B, Fig. 2) of 10-m length attached to the fix line with a float fixed at the opposite end, stretching the lines in a vertical position.

The first test MACR was deployed in March 2010 and the growth lines attached were not seeded. After a successful structural testing period of three years, the growth lines were replaced with seeded lines with respectively S. latissima and Laminaria hyperborea (Gunnerus) Foslie. This deployment was meant as a biological test of growth. Unfortunately, these results were not consistent enough for scientific 


\subsection{Seeding method}

Seeding material was produced by the company Hortimare BV, located in Norway and the Netherlands, using a standard procedure for kelp sporulation [42]. Fertile S. latissima and A. esculenta were collected from wild populations in Funningsfjørður in January 2014. From the sterilized fertile sori, spore release was done by leaving the sori dehydrating and in darkness until next day. The spores were released to sterile and filtrated seawater and placed with aeration in red light at $10 \pm 2{ }^{\circ} \mathrm{C}$. The gametophytes were nursed till sufficient biomass was reached (cultivated in vitro for $>9$ months). Hereafter, an induction period using white light was initiated. The gametophytes developed into juvenile sporophytes within two weeks (size $<1 \mathrm{~mm}$ ). Density of the seeding material was approximately $0.04 \mathrm{~mL} \mathrm{~m}^{-1}$ seeded line or a minimum of 200 sporophytes $\mathrm{m}^{-1}$. The juvenile sporophytes were seeded on 2-mm lines using a binder-mixture 


\subsection{Multiple partial harvesting}

The biomass of $S$. latissima was harvested in early summer (27/5-29/6) and late summer (24/7-24/8) during 2015 and 2016 by the company Ocean Rainforest Sp/f. The harvest method was manual cutting with a knife. Only the blades were cut off; leaving hold-fast, stem and 5-15 cm of the blade. This cutting length was used to ensure preservation of the meristematic zone to allow re-growth (Fig. 3). The biomass of $A$. esculenta was also harvested by the non-destructive multiple partial harvesting, once in the summer 2015 and twice in the summer 2016. The optimal cutting length of $A$. esculenta has not been described previously, because the multiple partial harvesting method has not been tested for this species before. Hence, the $A$. esculenta was harvested in two different ways to find the optimal cutting length. At this farm scale level of cultivation, it was not possible to perform a randomized experimental design. Consequently, the two types of treatment were placed after each other on the fix line with 25 lines of each treatment uninterrupted. One half of the lines ( $n=25)$ was cut proximally to the sporophylls, only leaving holdfast and part of stem, and 


\subsection{Yield, processing and storage of harvested biomass}

The harvested macroalgal biomass was transported in large plastic containers $(123 \times 103 \times 75 \mathrm{~cm} ; 660$ L) from the boat to the processing facilities. The biomass was cleaned carefully with seawater, before it was either dried at $35{ }^{\circ} \mathrm{C}$ for $1-2$ days and packed in boxes of $80 \mathrm{~kg} \mathrm{dw}$, or immediately frozen in a chest freezer at $-40{ }^{\circ} \mathrm{C}$ and stored at $-20{ }^{\circ} \mathrm{C}$ in boxes of $10 \mathrm{~kg} \mathrm{ww}$.

The harvested and packed macroalgal biomass was used to describe yield. Discarded biomass was, therefore, not included in final yield calculation. Though the discarded biomass was estimated to be less than $25 \%$ of total harvested biomass, this needs to be considered as an error source of yield calculations. The macroalgal biomass was occasional discarded on-board at sea, if it was covered by severe fouling, or during packaging, if colour/appearance or taste was not right. In an optimal production situation, there will be zero waste as discarded biomass will be used as feed, fertilizer, or extraction for high value molecules.

To compare the yield from this work with those described in the literature, the productivity was calculated as: yield per unit of space per year. The productivity of one MACR ( $\left.\mathrm{Y}_{\mathrm{MACR}}\right)$ was the total harvested yield $\left(\mathrm{Y}_{\text {Total }}\right)$ from MACR1 and MACR2 divided by number of rigs $\left(\mathrm{N}_{\text {rigs }}\right)$ and divided by the years of harvests from the same lines $\left(\mathrm{N}_{\text {years }}\right)$ :

$$
Y_{M A C R}=Y_{\text {Total }} / N_{\text {rigs }} / N_{\text {years }}=\mathrm{kg} d \mathrm{w} / \mathrm{rig} / \mathrm{yr}
$$




\subsection{Conversion factor between fresh and dry macroalgae biomass}

In all calculations of wet weight (ww) biomass to dried biomass ( $\mathrm{dw}$ ) or opposite a conversion-factor of 10:1 was used [43-44]. All cultivation results described as yield in dw, and reference to results from the literature was also described as dw, but also as ww, if they were initially recorded or presented in ww. 


\subsection{Growth measurement}

Growth of S. latissima deployed in November 2014 was monitored monthly over a period of two years. For each meter the six longest algal individuals were measured as technical replicates. The average of each meter was used to describe the average maximal length and compared with biological replicates $(n=3)$. The length was measured from growth line to tip of alga. The length was measured at five different depth intervals (1-2, 3-4, 5-6, 7-8 and 9-10 MBSL) and the average length of the vertical growth line was used $(n=3)$. Note that the surface meter was not used, though this was often the best producing meter, but here other species often overtook the line e.g. A. esculenta and Laminaria digitata (Hudson) J.V. Lamouroux. The average maximal length was used for statistical treatment to compare replicate lines, cultivation in depth, and in different seasons.

Also, the number of visible individuals on each meter was counted and used in the data treatment. Number of individuals and average maximal length provided a comparable dataset for growth under various conditions, but was not used to calculate the yield.

Finally, a field inspection was made to determine length and yield per meter line and at different depths prior to harvesting. The average maximal length of the macroalgae on the inspection days was the same data as for the seasonal variation in growth. For the yield calculations, a meter of line was harvested and weighted on board using a hand-held scale $(n=2-4)$. The field inspections were made May 2015, Aug 2015, and May 2016 at ten different depths $(0-1,1-2, \ldots$ 9-10 MBSL). These numbers of yield serve as a yield-calculation without errors of discarded biomass.

The study did not include a control treatment: non-harvested lines growing throughout 2014-2016. Data of growth and yield could, therefore, not be compared to non-harvested reference lines.

\subsection{Formulation of cost functions}

To show the underlying cost structure of macroalgal cultivation using a MACR we formulated the cost functions. The yearly cost of investment in terms of capital expenditure (CAPEX) on a MACR was 

a rig was subdivided into the sum of material costs $\left(\mathrm{MC}_{\mathrm{RIG}}\right)$ and deployment costs $\left(\mathrm{DC}_{\mathrm{RIG}}\right)$ :

$$
T C_{R I G}=M C_{R I G}+D C_{R I G}
$$

The material costs $\left(\mathrm{MC}_{\mathrm{RIG}}\right)$ included costs of anchors, chains, the fix line, fittings, surface floats and signal buoys. The deployment costs (DC) were the hourly cost of vessel operation offshore, the hourly cost of labour and the total number of operation hours needed for deployment. To determine the total cost of the growth lines $\left(\mathrm{TC}_{\mathrm{GL}}\right)$ on a MACR-installation, the cost of a single growth line $\left(\mathrm{C}_{\mathrm{GL}}\right)$ was multiplied by the number of growth lines $\left(\mathrm{N}_{\mathrm{GL}}\right)$ :

$$
T C_{G L}=N_{G L} \cdot C_{G L}
$$

The deployment and installation of growth lines included material for preparation, strips, and tape, twining seed lines around growth lines and transport of growth lines for installation offshore on the fix line.

The operational expenditures (OPEX) involved cultivation offshore, monitoring, maintenance, and harvesting, and were formulated as follows:

$$
O P E X=O C \cdot N_{\text {harvests per year }}
$$

where $\mathrm{N}_{\text {harvests per year }}$ indicates the number of harvests in a year and $\mathrm{OC}$ is the operational cost for one growth period. The operational cost (OC) was the hourly cost of vessel operation offshore, plus the hourly cost of labour, multiplied by the number of hours spent on each inspection times the number of inspections in each growth period, plus the time spent on harvesting each growth line times by the number of growth lines.

$$
O C=\left(p_{\text {vessel }}+p_{\text {labour }}\right) \cdot\left(q_{\text {inspection hours }} \cdot N_{\text {inspections }}+q_{\text {harvesting hours }} \cdot N_{G L}\right)
$$

To determine the revenue function and the cost per unit macroalgae we identified the yield of harvested biomass during the growth period. The yield (Y) in $\mathrm{kg} \mathrm{dw}$ is calculated as:

$$
Y=G \cdot N_{G L} \cdot q_{\text {rope }} \cdot N_{\text {harvests per year }}
$$




\section{Results}

\subsection{Cultivation System}

Since deployment of the first MACR in March 2010 and the following two MACR's deployed in 2014, the installations have remained intact in the ocean and have proven themselves able to withstand the physical strains caused by the energetic wave climate and storms of the North Atlantic Ocean.

\subsection{Harvest and yield}

The two 500-m long MACR's that were deployed at the cultivation site in November 2014 had a total of 470 vertical 10-m long growth lines. The total of growth lines seeded with Saccharina latissima was 420 and for Alaria esculenta 50 lines. The $S$. latissima lines were partially harvested four times and the A. esculenta lines were partially harvested three times within the harvest season in 2015 and 2016 (Table 1). The total biomass harvested $\left(\mathrm{Y}_{\text {Total }}\right)$ over two years for all three seaweed species was $3,517.6 \mathrm{~kg} \mathrm{dw}$. The annual productivity of one MACR $\left(\mathrm{Y}_{\mathrm{MACR}}\right)$ was thus $879.4 \mathrm{~kg} \mathrm{dw} \mathrm{yr}^{-1}$.

Table 1. Results of multiple partial harvesting from two Macroalgae Cultivation Rig's (MACR) deployed offshore in the Faroe Islands. MACR 1 had 240 and MACR 2 had 230 of 10-m long growth lines attached. Results marked with * were estimated from total harvest of 2015 using number of lines harvested in each period. Results marked with \# were possibly overestimated because self-seeded Alaria esculenta growing on Saccharina latissima-lines were included in the yield calculation.

\begin{tabular}{|l|c|c|c|c|c|}
\hline Deployed: Nov. 2014 & MACR & $\mathbf{1}^{\text {st }}$ harvest & $\mathbf{2}^{\text {nd }}$ harvest & $\mathbf{3}^{\text {rd }}$ harvest & $\mathbf{4}^{\text {th }}$ harvest \\
\hline \multirow{2}{*}{ Harvest periods } & 1 & $\begin{array}{c}\text { May/June } \\
2015\end{array}$ & $\begin{array}{c}\text { July/Aug. } \\
2015\end{array}$ & $\begin{array}{c}\text { May/June } \\
2016\end{array}$ & $\begin{array}{c}\text { July/Aug. } \\
2016\end{array}$ \\
\cline { 2 - 6 } & 2 & June 2015 & $\begin{array}{c}\text { Aug./Sept. } \\
2015\end{array}$ & $\begin{array}{c}\text { May/June } \\
2016\end{array}$ & Aug. 2016 \\
\cline { 2 - 6 }
\end{tabular}




\begin{tabular}{|c|c|c|c|c|c|}
\hline \multirow[t]{2}{*}{ Days used } & 1 & 8 & 9 & 7 & 4 \\
\hline & 2 & 4 & 6 & 9 & 3 \\
\hline \multirow[t]{2}{*}{ Meters harvested } & 1 & 610 & 1700 & 1600 & 1400 \\
\hline & 2 & 830 & 1250 & 1980 & 1330 \\
\hline \multirow[t]{2}{*}{$\%$ harvested of total deployed } & 1 & $25 \%$ & $71 \%$ & $67 \%$ & $58 \%$ \\
\hline & 2 & $36 \%$ & $54 \%$ & $86 \%$ & $58 \%$ \\
\hline \multirow[t]{3}{*}{ Yield S. latissima in total } & $\mathrm{kg} \mathrm{dw}$ & 347.2 & $\mathbf{7 8 7 . 8}$ & 1026.3 & 527.4 \\
\hline & meter line & $* 1190$ & $* 2700$ & 3080 & 2230 \\
\hline & $\mathrm{kg} \mathrm{dw} \mathrm{m} \mathrm{m}^{-1}$ & $* 0.292$ & $* 0.292$ & 0.333 & 0.237 \\
\hline \multirow[t]{3}{*}{ Yield $A$. esculenta in total } & $\mathrm{kg} \mathrm{dw}$ & $\mathbf{0}$ & 416.8 & 165.4 & 28.8 \\
\hline & meter line & & $\# 500$ & $\# 250$ & $\# 250$ \\
\hline & $\mathrm{kg} \mathrm{dw} \mathrm{m}{ }^{-1}$ & & 0.834 & 0.662 & 0.115 \\
\hline Yield $L$. digitata in total & $\mathrm{kg} \mathrm{dw}$ & $\mathbf{0}$ & $\mathbf{0}$ & 113.3 & 104.6 \\
\hline Total harvested yield $\left(\mathrm{Y}_{\text {Total }}\right)$ & $\mathrm{kg} \mathrm{dw}$ & & & & $3,517.0$ \\
\hline
\end{tabular}

On average, one MACR was harvested within 6.25 working days. Mean handling time per line \pm SD was $10 \pm 5 \mathrm{~min}$ from the first three harvests not including the time used to arrive at the location. The time used for sailing was not included thus comparison between studies is possible even though the cultivation sites are placed at different distance from a harbour.

After introducing modifications on the deck of the harvesting vessel the handling time was reduced to $8 \pm 1 \mathrm{~min}$ in average per line $\pm \mathrm{SD}$ (Table 1). These modifications consisted of a frame that was made from 2-m long PVC pipes, $15 \mathrm{~cm}$ in diameter, standing vertically in a square on the vessel. Between each of the vertical pipes similar horizontal pipes were attached. When harvesting a line, the vessel crane pulled up a line and placed it on top of the frame. Hereafter, the macroalgae was harvested using gravity into storage plastic containers on board. The new harvest method using a frame reduced average working days on one MACR to 3.5 days of harvesting per MACR compared to the 6.25 days (Table 1). The macroalgae biomass was stored in containers on board and in average $2.6 \pm 1.1$ (mean $\pm \mathrm{SD}$ ) line would fill one container.

Harvested yield was registered (weighted) after either drying or freezing. This meant that discarded biomass during handling were not registered. Also, the yield left on lines for re-growth was not monitored or used in yield calculation. This must be kept in mind when comparing yield between studies. For each 
harvest, not all growth lines were cut (Table 1). The excluded lines were either affected by entanglement, had too low yield or were used for other purposes than sale e.g. research.

All the biomass was sold mainly as dried for the food market, and a small quantity as frozen to the cosmetic industry. The sale strategy is based on a "business to business" market implicating that the company Ocean Rainforest $\mathrm{Sp} / \mathrm{f}$ does not carry its own retail brand.

\subsubsection{Saccharina latissima}

The multiple partial harvesting method was used when S. latissima was harvested and the yield increased at each harvest from the first to the third (Fig. 4). Though, the fourth harvest in July/August 2016 had a lower total yield than the previous. The total harvested biomass of S. latissima from two years was $2688.7 \mathrm{~kg} \mathrm{dw}$. This yield represented harvest of $9200 \mathrm{~m}$ of growth line distributed over four harvests of two MACR's (Table 1). The variation in yield between the different growth lines was large (0.35-7.66 kg dw per line). The average yield per metre of line was determined by field inspections and from total yield per harvest divided by metre of harvested lines. The average yield per metre determined from inspections showed a significant increase between each harvest (One-way ANOVA, $\mathrm{P}=0.0004, \mathrm{n}=5$; Fig. 5). The average yield per metre also increased between the first harvests looking at the harvest yield data (Fig. 5), but it decreased for the fourth one. The macroalgae harvested during 2015 was registered only from the year of harvest and not specified to the harvest turns. Accordingly, the yield of 2015 was divided between the two harvest turns by the number of lines harvested in each turn ( $1^{\text {st }}$ or $2^{\text {nd }}$ harvest $)$. This number was known due to a registration system used on-board of the vessel of harvested lines (Fig. 4). The average yield per meter in 2015 was accordingly calculated from a total amount harvested biomass divided by total lines harvested in 2015. To improve the yield per meter calculation, the yield was also measured from field inspections before each harvest turn. The yield found from inspections, was hence more accurately describing the yield per meter growth line (Fig 5). 


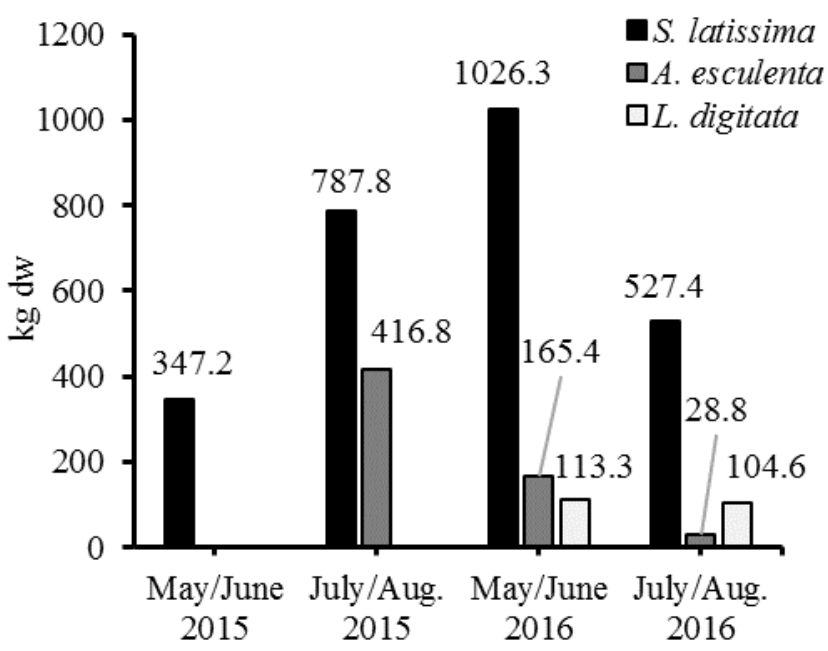

Fig. 4. Total yield from 4200-m Saccharina latissima and 500-m Alaria esculenta-lines in kg dry weight. The biomass was deployed offshore in the Faroe Islands in November 2014, and multiple partial harvested four times without re-seeding of growth lines. In 2016, self-seeded Laminaria digitata had overtaken some lines or part of lines. All three species were harvested, dried or frozen and sold to the food and cosmetic market. The yields represent biomass ready for sale; discarded biomass and biomass left for re-growth were not included.

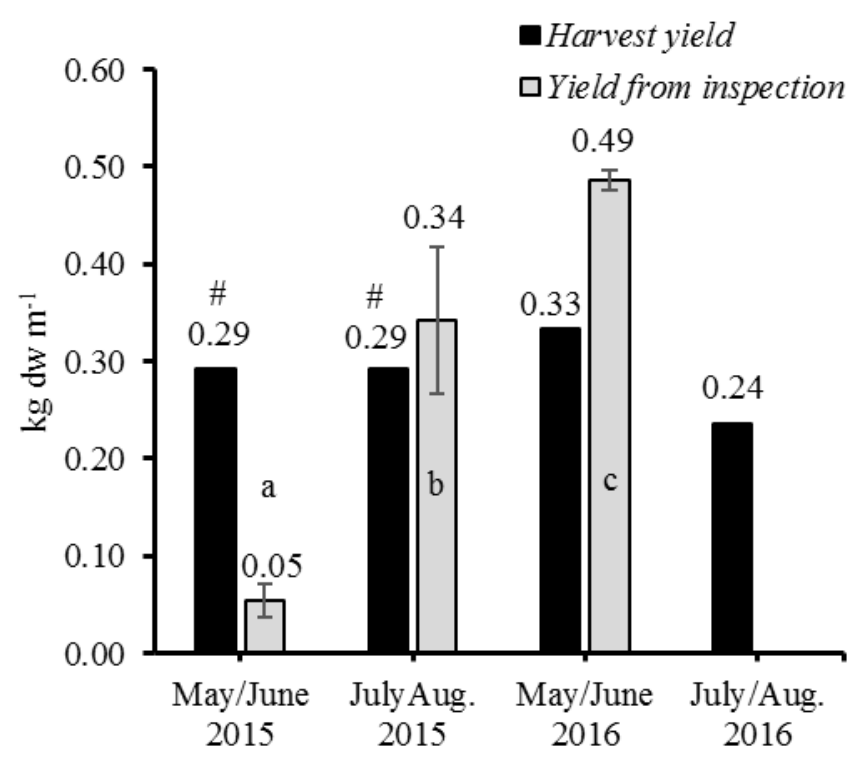

Fig. 5. Average yield of Saccharina latissima in dry weight of one-meter growth line. The biomass was deployed offshore in the Faroe Islands in November 2014, and multiple partial harvested four times without re-seeding of growth lines. Yield per meter was determined either by harvested biomass divided by meter of harvested line (black) or by field inspections ( $\mathrm{n}=5$ ), error bars represent standard deviation. Statistical different harvest yields are marked with different letters. Pillars marked with \# was calculated from 
the total 2015-yield and not for each harvest. The yield represents biomass ready for sale and discarded biomass and biomass left
for re-growth were not included.

\subsubsection{Alaria esculenta}

Re-growth from multiple partial harvest of cultivated A. esculenta was not previously tested. After deployment in November 2014, A. esculenta was partially harvested the first time in summer 2015. In early spring 2016 re-growth was observed. The re-growth proved that multiple partial harvest of this species is possible. The algae were cut in two different ways (see method and material section 2.4) and only lines cut distally of the sporophylls showed re-growth.

First harvest of A. esculenta in July 2015 had a total yield of $417 \mathrm{~kg} \mathrm{dw}$ from 500-m growth line (Fig. 4). This gives an average yield per meter growth line of $0.834 \mathrm{~kg} \mathrm{dw}$ per metre. This yield per meter is not a valid estimation, because self-seeded A. esculenta on S. latissima lines were also harvested and counted together with yield from seeded A. esculenta lines. An A. esculenta seeded line, had approximately a yield of 1-1.5 kg dw with the largest part growing on the first two MBSL (no data shown). For 50 lines, this would result in a yield between $50-75 \mathrm{~kg} \mathrm{dw}$. Hence, the harvested yield of 417 $\mathrm{kg} \mathrm{dw}$ was more than five times the yield one could expect. Consequently, we cannot describe the yield per meter growth line or conduct cost calculations for this species.

The second harvest of $A$. esculenta in May/June 2016 had a yield of $165 \mathrm{~kg}$ dw (Fig. 4), meaning an average yield of $0.33 \mathrm{~kg} \mathrm{dw}$ per meter calculated from $500-\mathrm{m}$ of growth line. This second harvest was crucial for proof of concept of multiple partial harvesting of A. esculenta, but not in terms of yield as half of lines were wrongly cut (proximate to the sporophylls) and had, therefore, no biomass. Consequently, a corrected calculation of average yield per metre of growth line was $0.66 \mathrm{~kg}$ dw per metre using harvest from 250-m of growth line. A. esculenta harvested from S. latissima growth lines was continuously used for sale and the yield of $A$. esculenta from these lines feeds into the total harvested yield and makes the calculation of yield per metre even more invalid. The wrongly cut lines were overtaken by self-seeded $L$. digitata.

The A. esculenta lines showed promising yield for the third harvest in early July 2016, but the biomass had deteriorated significantly one month later when the harvest was planned to take place. Only 
$28.8 \mathrm{~kg} \mathrm{dw}$ were harvested in August 2016 (Fig. 4). This observation advises to conduct the harvesting by mid-July at the latest.

\subsection{Seasonal variation and variation with depth of Saccharina latissima}

Saccharina latissima was harvested when maximal average length was 116.2 \pm 9.4 (mean $\pm \mathrm{SD}$ ) cm and the longest $S$. latissima individual was measured to $329 \mathrm{~cm}$. The highest growth was seen during summer (April-September) and degradation or low growth was seen during winter (November-February; Fig. 6). The seasonal growth pattern was interrupted by two harvests each year during summer months. A growth pattern not disturbed by harvesting was not monitored.

Each meter of growth line had a mean of $64.1 \pm 30.3($ mean $\pm \mathrm{SD})$ visible individuals. The large variation in density (Fig. 6) describes an uneven distribution of individuals on the growth lines. This gives room for optimised seeding techniques. There was a large decrease in density after second harvest, which could be due to the multiple partial harvest method. After third harvest, the density was again increasing to 80 individuals per meter. The explanation of this later increase might be self-seeding from wild populations.

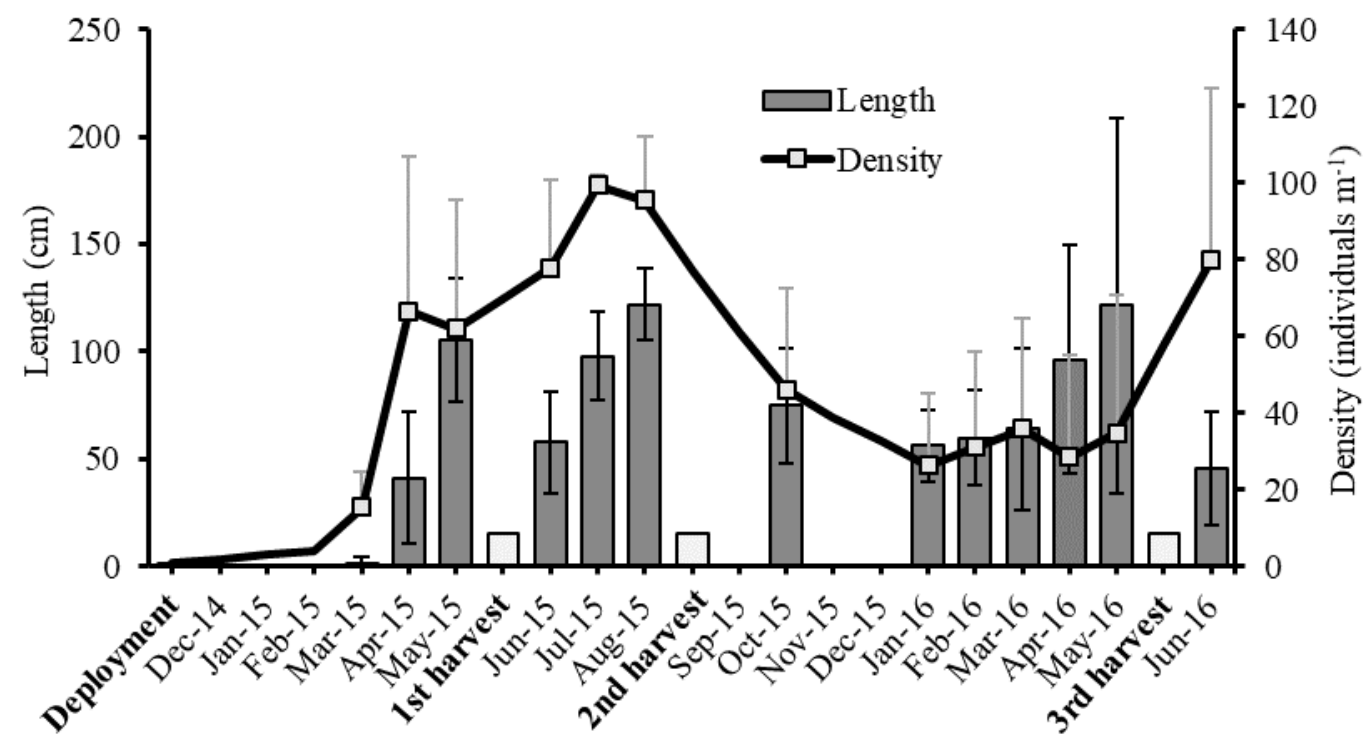

Fig. 6. Growth (average maximal length in $\mathrm{cm} \pm \mathrm{SD}$, black lines) and density (average number of visible individuals per meter + $\mathrm{SD}$, grey lines) of Saccharina latissima $(\mathrm{n}=15)$. The biomass was deployed on 10-m long vertical growth lines offshore in the Faroe Islands in November 2014, monitored monthly, and harvested three times by multiple partial harvesting. The blades were cut 5-15 
$\mathrm{cm}$ above growth line leaving holdfast, stem and part of blade with meristematic tissue. The length after harvest is illustrated as lighter pillars, though not measured.

The growth in depth by length is illustrate in Figure 7. To investigate the maximal cultivation depth below sea level a linear trend line was determined using the monitored growth of S. latissima at five depth intervals: 0-2, 2-4, 4-6, 6-8 and 8-10 MBSL (Table 2). The linear regression line of the lengthmeasurements showed that S. latissima in May/June 2015 had an increased length with increased depths (slope $1.65 \mathrm{~cm}$ ) and a mean length of the macroalgae of $99.60 \mathrm{~cm}$ at surface level $(0 \mathrm{MBSL})$, probably because no shading occurs when crop was still young (age $<6$ month), and in this way not light limited. The July/August 2015 harvest had a slight decrease in growth (slope $-3.79 \mathrm{~cm}$ ) with decreasing depths and a mean surface length of $125.6 \mathrm{~cm}$. The May/June 2016 harvest had a stronger decrease with depths (slope $-14.48 \mathrm{~cm}$ ) and a larger mean surface length of $208.9 \mathrm{~cm}$. The steeper slope found in May/June 2016 indicates that shading from the proximally algae is more significant for older lines. Hence, the growth during July/August 2015 and May/June 2016 showed light limitation with increased depths.

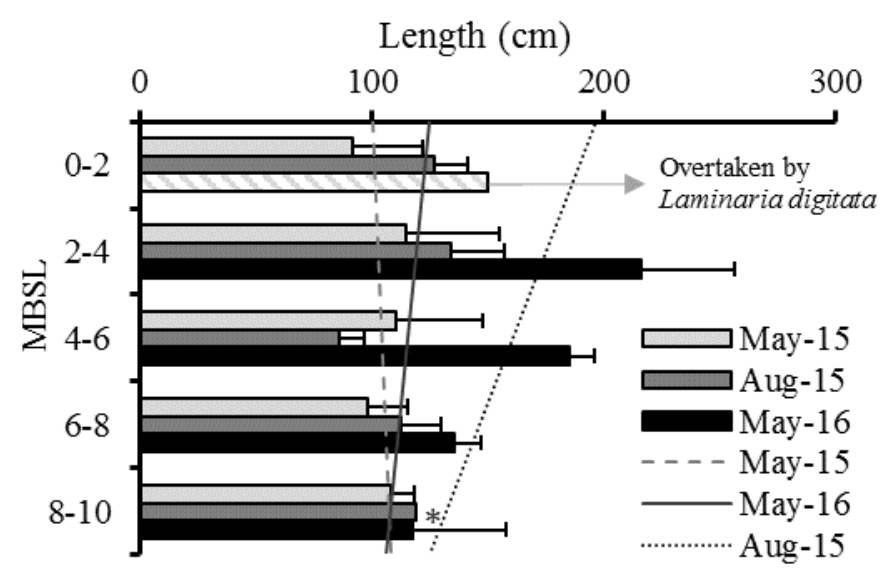

Fig. 7. Mean length in cm of cultivated Saccharina latissima $(\mathrm{n}=3)$, error bars represent standard deviation. The biomass was deployed on 10-m long vertical growth lines offshore in the Faroe Islands in November 2014, monitored before harvest in May and August 2015 and in May 2016. The length was measured in five different depth intervals 0-2, 2-4, 4-6, 6-8, and 8-10 meters below sea level (MBSL). For each season, a linear trend line was used to show growth trend with decreasing water depths. Pillar marked with * had one replicate. In the second year of cultivation the top meters (0-2 MBSL) were overtaken by Laminaria digitata. 


\begin{tabular}{|c|c|c|c|c|c|}
\hline \multicolumn{2}{|c|}{ Saccharina latissima } & May/June 2015 & July/Aug. 2015 & May/June 2016 & July/Aug. 2016 \\
\hline \multirow{4}{*}{ 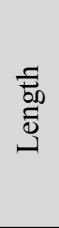 } & Linear trend line & $y=1.65 x+99.60$ & $y=-3.79 x+127.17$ & $y=-14.48 x+204.46$ & $\mathrm{~N} / \mathrm{A}$ \\
\hline & Mean length at surface $(\mathrm{cm})$ & 99.60 & 127.17 & 204.46 & \\
\hline & Max. cultivation depth (MBSL) & & 33.55 & 14.12 & \\
\hline & $\mathrm{R}^{2}$ & 0.0776 & 0.1053 & 0.3348 & \\
\hline \multirow{4}{*}{$\stackrel{\partial}{\circlearrowright}$} & Linear trend line & N/A & $y=-0.0384 x+0.7444$ & $y=-0.07 x+1.2655$ & $\mathrm{~N} / \mathrm{A}$ \\
\hline & Mean yield at surface $(\mathrm{kg} \mathrm{dw})$ & & 0.7444 & 1.2655 & \\
\hline & Max. cultivation depth (MBSL) & & 19.39 & 18.08 & \\
\hline & $\mathrm{R}^{2}$ & & 0.3988 & 0.4577 & \\
\hline
\end{tabular}

A similar pattern of slightly decreasing yield was seen from field inspection of yield $(\mathrm{kg} \mathrm{dw})$ at different depths (Fig. 8). Before harvest in July/August 2015 ( $2^{\text {nd }}$ harvest $)$ and May/June 2016 ( $3^{\text {rd }}$ harvest), the yield from each meter in general decreased with increased depth below surface, though some depthmeters had higher yield than the meter above. This pattern could generate from few data points, competition between species, or human disturbance (e.g. tangling of lines).

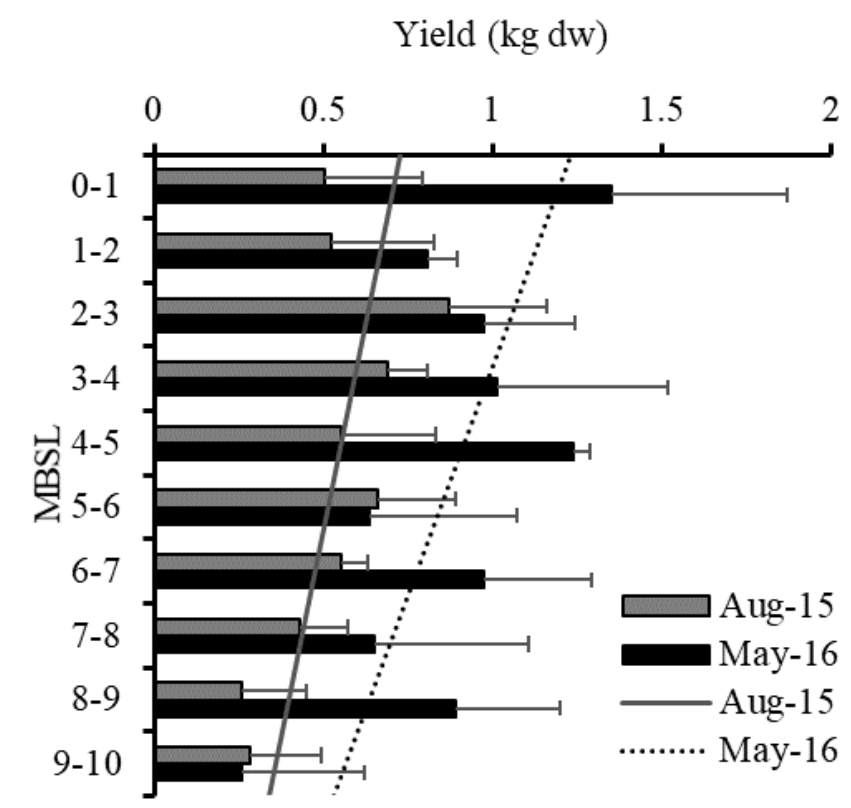


Fig. 8. Measured mean yield in kg dry weight (dw) per meter of Saccharina latissima growth line deployed in November 2014 offshore in the Faroe Islands (Aug-15 n=4, May-16 n=2), error bars represent standard deviation. The yield was monitored during field inspections before harvest in August 2015 and May 2016. The lines were harvested four times without re-seeding of growth lines (no data for yield before harvest in May/June 2015 and July/August 2016). Yield was found for each meter from sea surface to 10 meters below sea level (MBSL). For each season, a linear trend line was used to show growth trend with decreasing water depths.

The seasonal variation and the variation in growth with depths were normally distributed (ShapiroWilk normality test, alpha $=0.05$ ) and the data was, therefore, compared by a parametrical Tukey t-test (Two-way ANOVA, unpaired, alpha=0.05; Table 3). The interaction of depth and seasons was found significant $(\mathrm{p}<0.0001)$, indication that seasonal variation (light variation) influences the growth in depth. During summer when it is brighter the macroalgae can grow at deeper water depths than during winter were light is limited.

Table 3. Statistical output of an Ordinary two-way ANOVA, unpaired, Tukey test in GraphPad Prism 7.02. Alpha =0.05.

\begin{tabular}{|l|c|c|c|}
\hline Source of variation & \% of total variation & P value & Significant \\
\hline Interaction (depth x month) (df 36) & 22.93 & $<0.0001$ & Yes \\
\hline Months (df 12) & 39.43 & $<0.0001$ & Yes \\
\hline Depth (df 3) & 1.93 & 0.0258 & Yes \\
\hline
\end{tabular}

The take-home message is that yield decreases with depth as light decreases through the effects of attenuation and shading and the growth season in the Faroe Islands is from April to October where light intensity is highest.

\subsection{Analysis of cost and important scale aspects}

The cost per kg cultivated S. latissima was determined from capital expenditure (CAPEX), operational expenditure (OPEX) and yield (Y) (Table 4). The cost of A. esculenta was not conducted because of 1) unrealistic average yield per metre of growth line, 2) half of the lines were harvested by a wrong method, and 3) a significant deterioration of biomass was seen during July/August 2016. 
Table 4. Cost calculations for cultivated kelp at an offshore and exposed site in the Faroe Islands using the special designed Macroalgae Cultivation Rig (MACR). This case represents one MACR seeded with 2500 meters of Saccharina latissima.

\begin{tabular}{|c|c|c|c|c|c|}
\hline Case: One MACR with Saccharina latissima & Equation & $\begin{array}{c}\text { Base } \\
\text { scenario }\end{array}$ & \multicolumn{3}{|c|}{$\begin{array}{c}\text { Alternative } \\
\text { scenarios }\end{array}$} \\
\hline \multicolumn{6}{|l|}{ Production data } \\
\hline Total meters of growth line & $\mathrm{N}_{\mathrm{GL}} \cdot \mathrm{q}_{\mathrm{rope}}$ & 2,500 & 2,500 & 2,500 & 2,500 \\
\hline Years with same growth lines & & 1 & 1 & 2 & 3 \\
\hline No. of harvests per year & $\mathrm{N}_{\text {harvests }}$ & 1 & 2 & 2 & 2 \\
\hline Total no. of harvests without re-seeding & & 1 & 2 & 4 & 6 \\
\hline Average yield per meter growth line per harvest ( $\mathrm{kg} \mathrm{dw})$ & G & 0.29 & 0.32 & 0.37 & 0.29 \\
\hline Total cumulated yield per meter growth line ( $\mathrm{kg} \mathrm{dw})$ & & 0.29 & 0.58 & 1.15 & 1.73 \\
\hline Total yield per growth line / $\mathrm{m}^{2}$ sea surface $(\mathrm{kg} \mathrm{dw})$ & & 2.88 & 5.75 & 11.50 & 17.25 \\
\hline Total yield per MACR / 1 ha ( $\mathrm{kg} \mathrm{dw})$ & & 718.75 & $1,437.50$ & $2,875.00$ & $4,312.50$ \\
\hline Annual yield of harvested biomass ( $\mathrm{kg} \mathrm{dw}$ ) & Y & 718.75 & $1,437.50$ & $1,437.50$ & $1,437.50$ \\
\hline \multicolumn{6}{|l|}{ Economic data } \\
\hline Cost of rig per year & $\mathrm{TC}_{\mathrm{RIG}} / \mathrm{d}_{\mathrm{RIG}}$ & $€ 6,800$ & $€ 6,800$ & $€ 6,800$ & $€ 6,800$ \\
\hline Cost of growth lines per year $(2500 \mathrm{~m})$ & $\mathrm{TC}_{\mathrm{GL}} / \mathrm{d}_{\mathrm{GL}}$ & $€ 14,900$ & $€ 14,900$ & $€ 7,450$ & $€ 4,967$ \\
\hline Capital expenditure per year & CAPEX & $€ 21,700$ & $€ 21,700$ & $€ 14,250$ & $€ 11,767$ \\
\hline Operating cost per year & OPEX & $€ 4,700$ & $€ 9,400$ & $€ 9,400$ & $€ 9,400$ \\
\hline Total cost per year & & $€ 26,400$ & $€ 31,100$ & $€ 23,650$ & $€ 21,167$ \\
\hline Total cumulated cost per MACR & & $€ 26,400$ & $€ 31,100$ & $€ 47,300$ & $€ 63,500$ \\
\hline \multicolumn{6}{|l|}{ Costs } \\
\hline Cost of rig per kg macroalgae (dw) & & $€ 9.46$ & $€ 4.73$ & $€ 2.37$ & $€ 1.58$ \\
\hline Cost of growth lines per kg macroalgae $(\mathrm{dw})$ & & $€ 20.73$ & $€ 10.37$ & $€ 2.59$ & $€ 1.15$ \\
\hline Operating cost per kg macroalgae (dw) & & $€ 6.54$ & $€ 6.54$ & $€ 6.54$ & $€ 6.54$ \\
\hline Total cost per kg macroalgae (dw) & & $€ 36.73$ & $€ 21.63$ & $€ 11.50$ & $€ 9.27$ \\
\hline
\end{tabular}

The cost calculations for S. latissima were based on the following assumptions: One MACR has a 500-m horizontal fix line with 250 growth lines attached to it, and each growth line is $10-\mathrm{m}$ long, so that the total growth capacity is $2500-\mathrm{m}$ of growth lines. The harvesting yield was based on the cultivation from two MACR seeded with S. latissima in November 2014 and harvested during 2015 and 2016. The result of this large-scale cultivation showed that S. latissima was suitable for harvest twice a year.

Based on findings within this survey, the average total cost $\left(\mathrm{TC}_{\mathrm{RIG}}\right)$ of installing one MACR was $€$ 34,000 , and the average total cost $\left(\mathrm{TC}_{\mathrm{GL}}\right)$ of installing the growth lines on one MACR was $€ 14,900$. The 


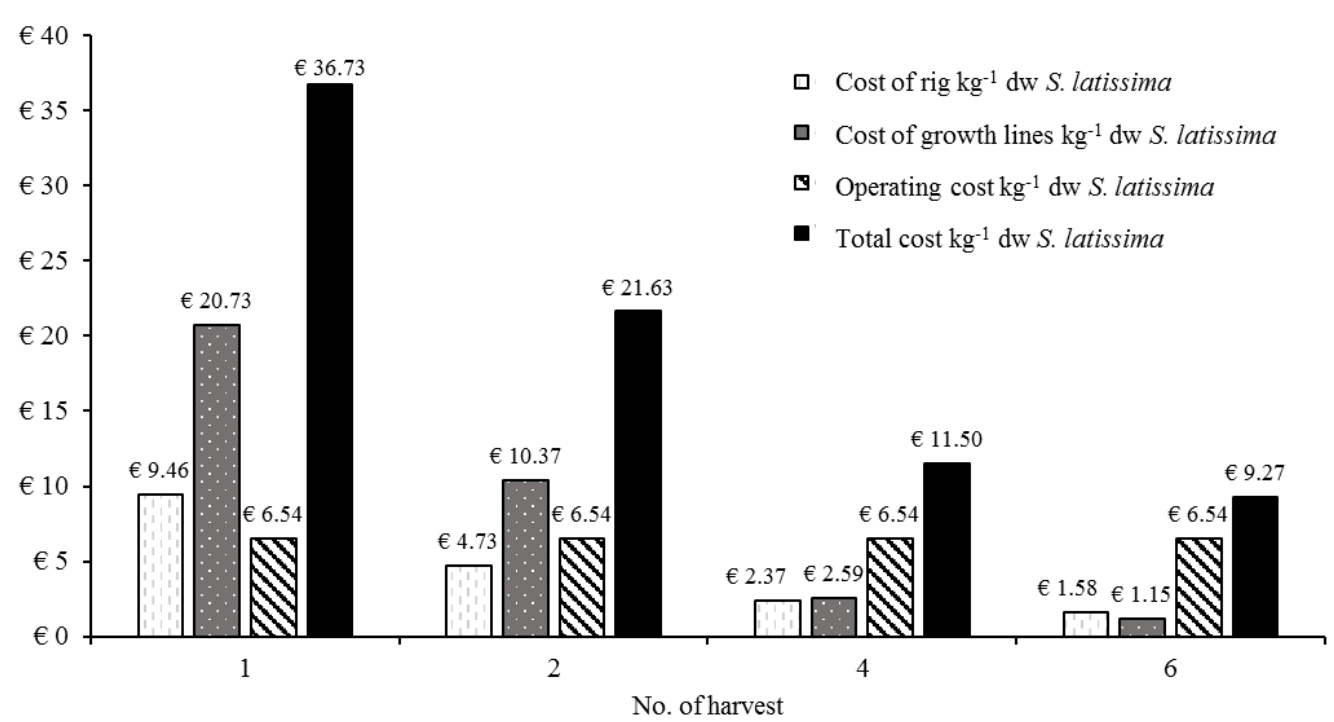

Fig. 9. Cost distribution for different number of harvests from the same growth lines with one (base scenario), two, four or six harvests without re-seeding. The calculation was based on data from two years of Saccharina latissima cultivation offshore in the Faroe Islands using two Macroalgae Cultivation Rig (MACR), a total of $5 \mathrm{~km}$ growth line.

The total cost per $\mathrm{kg} \mathrm{dw}$ cultivated biomass decreased from multiple harvesting (alternative scenarios) and the total cost per $\mathrm{kg}$ dw S. latissima ended at $€ 9.27$. The total cost of rig and growth lines per $\mathrm{kg} \mathrm{dw}$ biomass were declining due to the increase in yield from multiple harvests. However, the operational cost that relied on number of harvests per year and yield remained stable. 


\section{Discussion}

\subsection{Survivability of the Macroalgal Cultivation Rig}

The test of the MACR has proved that deployment of installation and growth lines, monitoring, and harvest is possible and easy to handle even though the test site was exposed to waves and placed at a location with a water depth of more than $50 \mathrm{~m}$. Its durability has been successfully determined to five years and the structures tested have survived the physical stress at the cultivation site since 2010. Based on these results, we consider the economic risk related to lost cultivation structures to be low.

The properties of a MACR for large-scale offshore macroalgal cultivation are e.g. the easy handling of the vertical growth lines that enables the production to switch from one species to another between harvests, thus optimising year-round utilisation and commercial performance. The detach of growth lines will, however, be somewhat challenging due to fouling growing on the knots. This can be prevented, if lines are handled frequently and, in this way, avoiding establishment of severe fouling.

Another advantage of the rig was the flexible structure of the growth lines, as they bend down to a horizontal position under severe weather conditions moving out of the damaging near sea surface zone. The flexibility was also important when boats were sailing through the cultivation area and the lines could bend or move away from the boat without being damaged.

Burg et al. [2] described the importance of a system that enables multiple harvests to reduce production costs, and this was successfully proven by the current work with four partial harvests within 16months. The approach of this work has demonstrated the potential for large-scale macroalgal production at deep-water locations in the North Atlantic region. 


\subsection{Multiple partial harvesting}

A common harvest method for Laminarian species has been to cut the entire blade right at the end of the fast-growing period lasting from January to May in Europe [5,27]. This method requires re-seeding following every harvest, and will, thus, result in higher cost compared to multiple partial harvesting. Several European studies have shown that harvest later than April/May resulted in high fouling, which made the application for food impossible [5,8,15-18]. The phenomenon of fouling appears to be coupled to relatively sheltered locations [5]. In contrast to other locations in Europe, the fast growing-period in the Faroe Islands was from March to October, and less fouling occurred as seawater temperature remained low $\left(<11^{\circ} \mathrm{C}\right.$ in summer). Instead of harvesting entire blades followed by re-seeding, this study presented a harvest method that partially cut the blade several times within the life span of the alga lowering the cost per unit macroalgae. Our outcome was most likely related to both physical conditions of the Faroe Islands and the harsh conditions of offshore cultivation: deep-sea location, strong current, and high wave actions (Section 2.1).

Our results showed that at least four harvests were possible without re-seeding S. latissima and three harvests for A. esculenta within a period of 16 months, when cut distally to the sporophylls. This has not been proven until now and has major impact on the cost related to seeding, growth lines, and deployment.

The most common harvest method, where the entire blade is cut off, was also used for Saccharina japonica in northern China after a two-years growth period. Zhang et al. [27] presented their average blade length of second-year algae to be $2.7 \mathrm{~m}$, having an average yield per alga of $0.14 \mathrm{~kg} \mathrm{dw}(1.4 \mathrm{~kg} \mathrm{ww})$, and a density of 14-16 individuals per metre of horizontal longline. In our study, S. latissima were harvested when the average maximal length was $116.2 \mathrm{~cm}$ and the sporophyte density was 64 individuals per metre of line (average of all harvests, Fig. 6). The average yield from all depths and from all four harvests was $0.29 \mathrm{~kg} \mathrm{dw}$ per meter (total harvested biomass, Fig. 5). Initially, the method used in the northern China seems to generate a higher yield per metre. On the other hand, did our cultivation have the advantage of four harvests without re-seeding, and the use of vertical cultivation lines, thus expanding the cultivation 
from $2 \mathrm{D}$ to $3 \mathrm{D}$. The question is therefore if higher density, less biomass, $3 \mathrm{D}$ cultivation, and a multiple partial harvesting is preferable instead of one harvest of the entire alga in the second year of cultivation?

Zhang et al. [27] had a yield per meter horizontal growth line of $2.21 \mathrm{~kg} \mathrm{dw}(=0.138 \mathrm{~kg} \mathrm{dw}$ per alga * 16 individuals per meter), corresponding to yield per $\mathrm{m}^{2}$ sea surface not including handling space. In our case, using multiple partial harvesting, the yield per $\mathrm{m}^{2}$ sea surface was $11.5 \mathrm{~kg} \mathrm{dw}$ (Table 4). Almost five times more than Zhang et al. [27].

Opposite numbers were seen when including handling space as Zhang et al. [27] used 100-meterlong horizontal lines with four meters in between the lines. This was equal to 25 lines in one hectare given in total $2500-\mathrm{m}$ growth line in one ha. The total yield per ha including handling space was therefore 5,527.0 $\mathrm{kg} \mathrm{dw}(=2.21 \mathrm{~kg} \mathrm{dw} * 2500 \mathrm{~m}$ line). In our case with $S$. latissima, the yield per ha from four harvests including handling space was $2,875 \mathrm{~kg} \mathrm{dw}$ (Table 4). Only half the yield of Zhang et al. [27].

This emphasises, that yield per area is very depended on the way it is estimated, and the cultivation method used. The reverse difference, that was seen when comparing yield per $\mathrm{m}^{2} \mathrm{vs}$. yield per ha, must relate to whether space used for handling is included or not. Yet, space-related issues are less important when using an offshore cultivation sites, as these sites are often less utilised.

The productivity potential of the system used in the Faroe Islands will properly improve over time and does not yet reflect the large scale commercial potential. However, these data are one examples of real world outputs from offshore cultivation and provide a reality check as to what can be achieved in high latitude areas of production.

In theory, the multiple partial harvesting method should reduce the growth rate, because Laminarian species grow the new blade from the meristem between the stipe and the blade using photosynthetic translocation from the old part of the blade to the meristematic sink [45]. Unfortunately, no lines were left as control lines (not harvested) and the effect on growth and yield of multiple partial harvesting still need more investigation.

Multiple partial harvesting was shown suitable in the Faroe Islands, and this can be explained by lower seawater temperatures, and accordingly lower fouling rates. Lower fouling rates, enabled the algae to grow throughout the summer and for several years. Another explanation could be that nitrate was 
available for macroalgal growth throughout the year in the Faroe Islands [46], and thus the algae could regrow even without the older blade part. Nitrate levels have been measured by the Marine Research Institute on the Faroese continental shelf since 1995 [47], and only three times was the nitrate concentration observed to drop below $3 \mu \mathrm{M}$, which is the limiting level for S. latissima. The geographical location of the cultivation site at the mouth of a fjord makes the site more comparable to continental shelf conditions than to fjord conditions.

In addition, to favourable nitrate conditions for macroalgal growth, temperature and salinity were extremely stable throughout a year, and based on Gaard et al. [47] the light-compensation depth measured in a Faroese fjord was below $10 \mathrm{~m}$ depth throughout the year except in December and January, where it could be as shallow as $5 \mathrm{~m}$ depth. The $10 \mathrm{~m}$ long growth lines used in this work are thus above the compensation depth nearly throughout the entire year.

Zhang et al. [27] reported that approximately $90 \%$ of the annual blade production was lost due to erosion at the blade tip. A continual multiple partial harvesting could possibly decrease the loss of biomass because the blades were cut when they were still relatively young and with fresh cell tissue. This might also decrease the level of biofouling on the blades because the fouled blade portions infested in spring are removed in July, and therefore not spread to blade tissue newly grown in the interval between July and October.

In addition, the conditions of the offshore cultivation site with high current, large water column, and longer distance to naturally established populations could be the explanation of a very low biofouling density covering the macroalgae.

In comparison with cultivation trials in the North Sea [2,5], we found it possible to cultivate $S$. latissima also through summer and that we could keep the same seeding material over more years. Our findings support the observations of Wegeberg et el. [28] who emphasized the high potential for macroalgal cultivation in the Faroe Islands due to a relatively large ocean area and stable nitrate and temperature levels throughout the year.

Mols-Mortensen et al. [29] found that the quality of cultivated S. latissima measured by protein concentration and essential amino acid score was significantly higher in May and June compared to July 


\subsection{Optimised yield}

Although the MACR has provided promising results, there is still a need to improve the rig, especially to reduce the handling in relation to harvesting and operational cost. To increase the total production per area sea surface, future constructions could be improved by lengthening the growth lines e.g. to $20 \mathrm{~m}$. This would decrease the production cost per meter of cultivated macroalgae and increase the yield per $\mathrm{m}^{2}$ sea surface. In the inner Danish seawaters, S. latissima can in theory grow down to 12-14 MBSL during the summer period at sites with low light attenuation [50]. In comparison, our findings suggest a maximal cultivation depth of 18-19 m (Table 3). But, the yield at these lower meters is not yet known, and the optimal cultivation depth (length of growth lines) is currently being tested in situ in the Faroe Islands. The final maximal cultivation depth will depend on yield per lowest meter and total cost per meter growth line. The significant variation in growth during different months and at different depths depends on the amount of light throughout the year and the transmittance of light in the water column. Nutrient level and seawater temperature are not likely to play a major role determining seasonal growth performance as these are predominantly constant year-round and seawater masses are fully mixed at the cultivation site. Two factors complicate the calculation of expected yields at different depths. Firstly, cultivated macroalgae will have a shading effect on the underlaying alga and secondly, growth lines will move with the current. As a result, it is necessary to conduct a tentative cost-benefit analyses of cultivation in deeper depths or establish in situ experiments. The linear trend lines (Table 2$)$ showed very low correlation-coefficients $\left(\mathrm{R}^{2}<0.45\right)$ for all harvests. The variation with depth was better described by a 2-grade polynomic trend line (data not shown), because the lines had the lowest yield near surface and at the lowest depths (8-10 MBSL). The decrease of yield with lower depths was proposed by the attenuation of light through water column [50]. The lower 
yield in the first meters below sea level, was most likely due to interspecific competition between species, as from A. esculenta and L. digitata which was often found at this upper part of the lines. These two species had thus a better survival at more wave exposed sites, and with occasional high light intensities.

The results show a large variation in the yield between the different growth lines, which is a challenge for large-scale production. One way of improving the production is to increase yield per meter growth line. Uniform sporophyte density and growth are considered important to obtain a higher yield and more stable supply to the market. A way to optimize yield is to understand the seasonal variation in growth and use this knowledge in determining the optimal timing for deployment and harvesting. Selective breeding will also have a major role in optimising yield as seen from Asian macroalgal cultivation and in the agriculture sector. This is therefore an important topic in future research.

Also, the yield and quality are very much dependent on low levels of fouling, and grazing animals. This study demonstrated a very clean biomass of primary food quality, although there was more fouling during the late summer harvest than spring harvest. A mean reduction in expected biomass for third harvest of $A$. esculenta could be due to grazing animals. Understanding the behavior of the grazing animals living in offshore artificial macroalgal fields is therefore of paramount importance. Nevertheless, the offshore cultivation site is considered to contribute towards the low amount of fouling. Our findings support the theory of Arrontes [51], Mols-Mortensen et al. [29], and Bruhn et al. [5] who recommend avoiding sheltered cultivation areas and instead benefit from more open sea areas with stronger currents, lower nutrient levels, and lower and more stable temperatures.

Finally, the business case will be improved by utilizing $100 \%$ of the harvested biomass. In such case discarded macroalgae will be used in a zero-waste production and sold as fertilizer, feed and/or be used in the extraction of high value products e.g. fucoidan.

\subsection{Cost of offshore cultivation}

The cost calculation was based on empirical data generated through the harvest periods 2015 and 2016. From the cost calculations, it was clear that the variable yield (dw per meter of growth line per 
harvest) had a major influence on the overall economic performance expressed in cost per kg macroalgae. However, the most important finding was the impact of the multiannual harvest on the economic performance, with a $75 \%$ reduction of cost per $\mathrm{kg}$ cultivated S. latissima in the maximum cultivation scenario with six harvests per growth line deployed, compared to one harvest in the base scenario. This means that the capital expenditures (CAPEX) per kg was reduced by factor 2-6 depending on the number of harvests made from the same growth lines without re-seeding. This was a result of the very suitable physical conditions in the Faroe Islands combined with offshore cultivation to reduce fouling. In addition, in a large-scale deployment scenario the CAPEX will be reduced as a function of economy of scale related to equipment production and installation.

There was also room for improvements in the operational cost per year (OPEX). The need for innovation in relation to the operations was evident as it remains equal for the various scenarios. The main OPEX cost reduction driver will be increased mechanisation of seeding and harvesting processes. Furthermore, increased know-how through years of operation will reduce expenditures related to inspections of cultivation lines. In addition, an overall improvement of harvested yield per metre or area, e.g. because of a selective breeding program, will reduce the cost per $\mathrm{kg}$ of the harvested biomass.

In addition, continuous innovation and climbing learning curves are expected to improve operational efficiency. The improved harvest system using a frame on board to hold the lines was first step to optimize harvesting, however a bigger step will be to develop mechanical harvest equipment and thereby reduce the labour required for harvesting from e.g. three persons to one or two persons. It is important to bear in mind that the revenue will also be influenced by quality of the macroalgae, both fouling and biochemical composition, which varies with season.

It is expected that the cost will be reduced by economy of scale in large-scale cultivation scenario both in terms of cost of MACR's and in terms of quantity tonnes biomass processed, but the scaling factor will need further investigation. Finally, reducing operating costs by economy of scale in large-scale cultivation scenario, the multiple partial harvesting method, and increasing yield per meter is vital for the commercial viability of offshore macroalgal cultivation. 


\section{Acknowledgements}

The authors are grateful for the financial support from Nordic Innovation in 2015 through grant number Mar-14324 (MacroValue) and by NORA-Nordatlantisk Samarbejde in 2013 through grant number 510-102 (MacroBiotech). The author Urd Grandorf Bak has received research grants from Innovation fund Denmark for an Industrial Ph.D. education (2016-2019).

The authors would like to thank Professor Matthew Dring for his constructive input and comments on the first manuscript version. Furthermore, the authors would like to acknowledge the important work conducted by Gilli Trónd and Rúni Joensen as concept inventors and designers of the offshore cultivation system MACR. Last, but not less important, the authors would like to thank all their colleagues at Ocean Rainforest $\mathrm{Sp} / \mathrm{f}$, who have helped make this research possible. 
1830

1831

1832

1833

1834

1835

1836

1837

1838

1839

1840

1841

1842

1843

1844

1845

1846

1847

1848

1849

1850

1851

1852

1853

1854

1855

1856

1857

1858

1859

1860

1861

1862

1863

1864

1865

1866

1867

1868

1869

1870

1871

1872

1873

1874

1875

1876

1877

1878

1879

1880

1881

1882

1883

1884

1885

1886 
[2] S.W.K. van den Burg, et al., The economic feasibility of seaweed production in the North Sea. Aquaculture Economics \& Management 20:3 (2016) 235-252.

[3] F. Fernand, et al., Offshore macroalgae biomass for bioenergy production: Environmental aspects, technological achievements and challenges, Renew. Sustainable Energy Rev. 75 (2017) 35-45.

[4] S. Kraan, In: Seaweed in Health and Disease Prevention, Chapter 6 - Seaweed and Alcohol: Biofuel or Booze?, Elsevier Inc. (2016) 169-184.

[5] A. Bruhn, et al., Impact of environmental conditions on biomass yield, quality, and bio-mitigation capacity of Saccharina latissima, Aquaculture Environment Interactions 8 (2016) 619-636.

[6] B. Charrier, et al., Furthering knowledge of seaweed growth and development to facilitate sustainable aquaculture, A viewpoint, New Phycologist (2017).

[7] D.P. Chynoweth, Report: Review of Biomethane From Marine Biomass. Review of History, Results and Conclusions of the "US Marine Biomass Energy Program" (1968-1990). Marine Agronomy (2002).

[8] G.S. Marinho, S.L. Holdt, I. Angelidaki, Seasonal variations in the amino acid profile and protein nutritional value of Saccharina latissima cultivated in a commercial IMTA system, J. Appl. Phycol. 27 (2015) 1991-2000. 
[11] E.A. Titlyanov, T.V. Titlyanova, Seaweed Cultivation: Methods and Problems, Russ. J. Mar. Biol. 36 (2010) 227-242.

[12] FAO - Food and Agriculture Organization of the United Nations Statistics Division, Global Aquaculture Production 1950-2015, Retrieved April 26, 2017. Available from:

http://www.fao.org/fishery/statistics/global-aquaculture-production/query/en.

[13] D. Valderrama, et al., The Economics of Kappaphycus Seaweed Cultivation in Developing Countries: A Comparative Analysis of Farming Systems. Aquaculture Economics \& Management 19:2 (2015) 251277.

[14] S. Zuniga-Jara, M.C. Marín-Riffo, C. Bulboa-Contador, Bioeconomic analysis of giant kelp Macrocystis pyrifera cultivation (Laminariales; Phaeophyceae) in northern Chile, J. Appl. Phycol. 28 (2016) 405-416.

[15] M.M. Nielsen, Cultivation of kelps for energy, fish feed and bioremediation. PhD thesis, Aarhus University, Denmark (2015).

[16] A. Handå, et al., Seasonal- and depth-dependent growth of cultivated kelp (Saccharina latissima) in close proximity to salmon (Salmo salar) aquaculture in Norway, Aquaculture 414-415 (2013) 191-201. 
[17] C. Peteiro, O. Freire, Epiphytism on blades of the edible kelps Undaria pinnatifida and Saccharina latissima farmed under different abiotic conditions. J. World Aquacult. Soc. 44 (2013) 706-715.

[18] S. Wegeberg, Cultivation of kelp species in the Limfjord, Denmark, Department of Biology, Copenhagen University, Denmark (2010).

[19] W.W. McNeary, L.E. Erickson, Sustainable Management of Algae in Eutrophic Ecosystems, J. Environ. Prot. 4 (2013) 11A.

[20] O.O. Sulaiman, et al., Mooring analysis for very large offshore aquaculture ocean plantation floating structure. Ocean Coast Manag. 80 (2013) 80-88.

[21] X. Fei, Solving the coastal eutrophication problem by large-scale seaweed cultivation, Hydrobiologia 512 (2004) 145-151.

[22] J. Ryan, Farming the deep blue, Report, September 2004.

[23] K.T. Bird, P.H. Benson, Seaweed Cultivation for Renewable Resources, Elsevier Science Pub. Co. Inc., New York, 1987.

[24] A.B. Flowers, K.T. Bird, Methane Production from Seaweeds, In: I. Akatsuga (ed.): Introduction to Applied Phycology. SPB Academic Publishers bv, The Hague, 575-587, 1990.

[25] B.H. Buck, C.M. Buchholz, The offshore-ring: A new system design for the open ocean aquaculture of macroalgae, J. Appl. Phycol. 16 (2004) 355-368. 
[26] C. Peteiro, Ó. Freire, Offshore cultivation methods affects blade features of the edible seaweed Saccharina latissima in a bay of Galicia, Northwest Spain, Russ. J. Mar. Biol. 37(4) (2011) 319-323.

[27] J. Zhang, et al., Growth and loss of mariculture kelp Saccharina japonica in Sungo Bay, China, J. appl. Phycol. 24 (2012) 1209-1216.

[28] S. Wegeberg, A. Mols-Mortensen, K. Engell-Sørensen, Sustainable production and utilization of marine resources in the Arctic, fish and seaweed (SPUMA), Scientific report from DCE - The National Center for Environment and Energy 82, Denmark, 2013.

[29] A. Mols-Mortensen, E. á Geilini Ortind, C. Jacobsen, S.L. Holdt, Variation in growth, yield and protein concentration in Saccharina latissima (Laminariales, Phaeophyceae) cultivated with different wave and current exposures in the Faroe Islands, J. Appl. Phycol., 22nd International Seaweed Symposium, Copenhagen, 2017.

[30] C. Peteiro, Ó. Freire, Effect of Outplanting Time on the Commercial Cultivation of the Kelp Laminaria saccharina at the Southern Limit in the Atlantic Coast (N.W. Spain), Chin. J. Oceanol. Limnol., 27:1 (2009) 54-60.

[31] J. Cremades, et al., Nuevo Método Para el Cultivo Industrial de Laminaria saccharina (Laminariales, Phaeophyta) en las Costas Gallegas in XI Congreso Nacional de Acuicultura, Cerviño Eiroa, A., Guerra Díaz, A. and Pérez Acosta, C., Eds., Vigo, Spain: Consellería de Pesca e Asuntos Marítimos, Xunta de Galicia (2007) 559-562.

[32] C. Peteiro, J.M. Salinas, Ó. Freire, C. Fuertes, Cultivation of the Autoctonous Seaweed Laminaria saccharina off the Galician Coast (NW): Production and Features of the Sporophytes for an Annual and Biennial Harvest, Thalassas 22:1 (2006) 45-52. 
[33] B.H. Buck, C.M. Buchholz, Response of offshore cultivated Laminaria saccharina to hydrodynamic forcing in the North Sea, Aquaculture 250 (2005) 674-691.

[34] V.A. Chugaynova, S.P. Gorennikov, Mariculture of Laminaria saccharina in the White Sea, Hydrobiol. J. 32:2 (1996) 63-67.

[35] J.M. Kain (Jones), T.J. Holt, C.P. Dawes, European Laminariales and their Cultivation in Economically important plants of the Atlantic: their biology and cultivation, Yarish, C., Penniman, C.A. and Van Petten, P., Eds., Groton: Connecticut Sea Grant College Program, University of Connecticut (1990) 95-111.

[36] G. Bruntse, T.E. Lein, R. Nielsen, Marine benthic algae and invertebrate communities from the shallow waters of the Faroe Islands, Kaldbak Marine Biological Laboratory, 1999.

[37] Landsverk, Ministry of the Interior, Tórshavn, the Faroe Island. Retrieved November 13, 2013. Available from: http://www.landsverk.fo/.

[38] G. á Norði, Ø. Patursson, Influence of waves and current speed on resuspension of fish farm waste: Case study in Funningsfjørður, Faroe Islands, Fiskaaling - Aquaculture research station of the Faroes, 2012.

[39] B.A. Niclassen, K. Simonsen, High resolution wave climate of the Faroe Islands, Technical Report, 2012.

[40] K.M.H. Larsen, B. Hansen, H. Svendsen, Faroe Shelf Water, Continental Shelf Research 28 (2008) $1754-1768$. 
[41] S.K. Eliasen, B. Hansen, Light in Faroese Waters, Technical Report No.: 03-01, The Faroese Fisheries Laboratory, Thorshavn, Faroe Islands, 2003.

[42] M. Edwards, L. Watson, Cultivating Laminaria digitata, Irish Sea Fisheries Board, Aquaculture Explained 26 (2011) 72.

[43] FAO - Food and Agriculture Organization of the United Nations Statistics Division, Handbook of Eucheuma Seaweed, 4. Harvesting and selling seaweed: "What care is required after seaweed is harvested?", $\quad$ Retrieved $\quad$ March $15, \quad$ 2018, Available from: http://www.fao.org/docrep/field/003/AC287E/AC287E04.htm

[44] Research Gate, Doctor Thierry Chopin added answer to the discussion: "What is the water content in the seaweed tissue?", 2015, Retrieved March 15, 2018. Available from:

https://www.researchgate.net/post/What_is_the_water_content_in_the_seaweed_tissue

[45] I. Bartsch, et al., The genus Laminaria sensu lato, Eur. J. Phycol. 43 (2008) 1-86.

[46] Havstovan, Faroe Marine Research Institute, the Faroe Island, Retrieved October 12, 2015. Available from: http://www.hav.fo/.

[47] E. Gaard, G. á Norði, K. Simonsen, Environmental effects on phytoplankton production in northeast Atlantic fjord, Faore Islands, J. Plankton Res. 33 (2011) 947-959.

[48] A. Bruhn, et al., Crude fucoidan content in two North Atlantic kelp species, Saccharina latissima and Laminaria digitata — seasonal variation and impact of environmental factors, J. Appl. Phycol. (2017) 29:3121-3137. 
[49] M.M. Nielsen, et al., Growth dynamics of Saccharina latissima (Laminariales, Phaeophyceae) in Aarhus Bay, Denmark, and along the species' distribution range, Mar. Biol. (2014) 161:2011-2022.

[50] U.G. Bak, Suitable cultivation areas for Palmaria palmata (Rhodophyta) and Saccharina latissima (Phaeophyceae) in the inner Danish waters in relation to variations in light, temperature and salinity, Master thesis, Roskilde University, Denmark, 2014.

[51] J. Arrontes, Composition, Distribution on Host, and Seasonality of Epiphytes on Three Intertidal Algae, Bot. Mar. 33 (1990) 205-211. 


\section{Declaration of authors contributions}

All persons designated as authors qualify for authorship, and are listed as authors. Each author has participated sufficiently in the work to take public responsibility for appropriate parts of the content.

All authors have made substantial contributions to the conception and design of the study, acquisition of data and/or analysis and interpretation of data. All authors have drafting the article and/or revising it critically for important intellectual content. And all authors have given their final approval of the version to be submitted

l.ist of authors

1. Urd Grandorf Bak (Corresponding Author)

2. Agnes Mols-Mortensen

3. Olavur Gregersen

\section{Declaration of authors agreement}

We the undersigned declare that the manuscript with the title: "Production method and cost of" commercial-scale offshore cultivation of Kelp in the Faroe Islands using multiple partial cutting (nondestructive harvests)" is original, has not been published before and is not currently being considered for publication elsewhere.

We confirm that the manuscript has been read and approved by all named authors and that there are no other persons who satisfied the criteria for authorship but are not listed. We further confirm that the order of authors listed in the manuscript has been approved by all of us.

We understand that the Corresponding Author is the sole contact for the Editorial process. He/she is responsible for communicating with the other authors about progress, submissions of revisions and final approval of proofs

7. August 2017

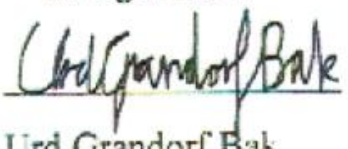

Urd Grandorf Bak

Denmark

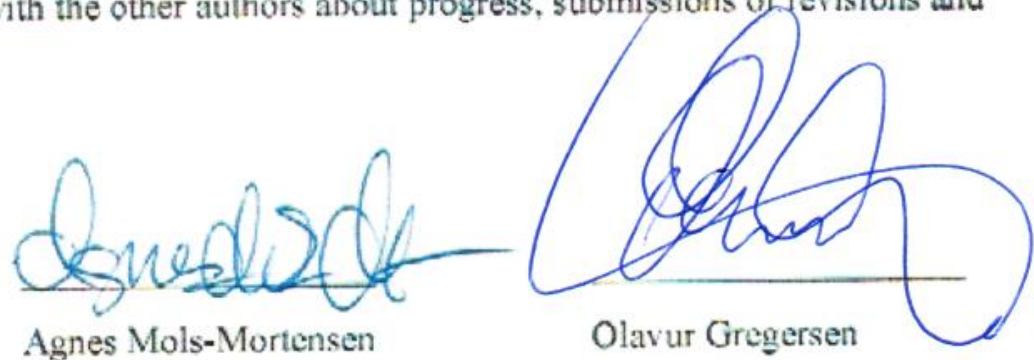

Faroe Islands 